NBER WORKING PAPER SERIES

\title{
SCHOOL-TO-CAREER PROGRAMS AND TRANSITIONS TO EMPLOYMENT AND HIGHER EDUCATION
}

\author{
David Neumark \\ Donna Rothstein \\ Working Paper 10060 \\ http://www.nber.org/papers/w10060 \\ NATIONAL BUREAU OF ECONOMIC RESEARCH \\ 1050 Massachusetts Avenue \\ Cambridge, MA 02138 \\ October 2003
}

\begin{abstract}
Neumark is Senior Fellow, Public Policy Institute of California; Professor of Economics, Michigan State University; and Research Associate, NBER. Rothstein is Research Economist, Bureau of Labor Statistics, U.S. Department of Labor. We are grateful to Daiji Kawaguchi and Jon Sonstelie, and seminar participants at the Public Policy Institute of California, for helpful comments. This work was partially supported by the Education Policy Center at Michigan State University. The views expressed are those of the authors and do not reflect the views or policies of the Public Policy Institute of California, the Bureau of Labor Statistics or its staff members, or the Education Policy Center. The views expressed herein are those of the authors and not necessarily those of the National Bureau of Economic Research.
\end{abstract}

(C)2003 by David Neumark and Donna Rothstein. All rights reserved. Short sections of text, not to exceed two paragraphs, may be quoted without explicit permission provided that full credit, including (C) notice, is given to the source. 
School-to-Career Programs and Transitions to Employment and Higher Education

David Neumark and Donna Rothstein

NBER Working Paper No. 10060

October 2003

JEL No. J18, J24, J60, I21

\begin{abstract}
The 1994 Federal School-to-Work Opportunities Act (STWOA) provided more than \$1.5 billion over five years to support increased career preparation activities in the country's public schools. However, the STWOA was not re-authorized, so state governments face decisions about levels of funding support for school-to-career (STC) programs. Coupled with the availability of a new longitudinal data source with rich information on STC programs - the 1997 National Longitudinal Survey of Youth (NLSY97) - it is therefore an opportune time to study the effectiveness of STC programs. This paper uses the NLSY97 to assess the effects of STC programs on transitions to employment and higher education among youths leaving high school, with a focus on estimating the causal effects of this participation given possible non-random selection of youths into STC programs.
\end{abstract}

David Neumark

Public Policy Institute of California

500 Washington Street, Suite 800

San Francisco, CA 94111

and NBER

neumark@ppic.org

Donna Rothstein

Bureau of Labor Statistics

2 Massachusetts Ave., NE

Suite 4945

Washington, DC 20212

rothstein.donna@bls.gov 


\section{Introduction}

The 1994 Federal School-to-Work Opportunities Act (STWOA) provided more than \$1.5 billion to support increased career preparation activities in the country's public schools. ${ }^{1}$ The STWOA was spurred by a concern among policy-makers and researchers that youth labor markets in the United States are overly chaotic, entailing unnecessary periods of joblessness, excessive job instability, and employment in dead-end jobs (U.S. General Accounting Office, 1990). This perception of the problem was aptly summarized in a report by the U.S. Office of Technology Assessment describing the existing system as producing youths who were "unmotivated in school and spend years bouncing from one lowpaying job to another" (1995, p. 3).

Congress passed the STWOA in response to three areas of particular concern for public education identified by researchers and educators. These were: (1) a lack of connection between school and work that led many youths to be unmotivated in school and to experience subsequent difficulty moving out of low-wage jobs; (2) youths completing school with insufficient skills needed for the labor market; and (3) increasing labor market demands for complex thinking, close teamwork, and the ability to learn on the job. The STWOA aimed to help young people develop the skills needed in the workforce and make better connections to careers through school-to-career (STC) transition systems, which fostered partnerships among schools, employers, and others (Office of Technology Assessment, 1995). Specifically, the STWOA set out to increase: (1) school-based initiatives such as career links to academic curriculum, and career-awareness activities; (2) work-based activities such as job shadowing, internships, and apprenticeships; and (3) connecting activities, such as the development of partnerships with employers and post-secondary institutions.

Spurred in part by funding provided to states under the STWOA, many states have implemented extensive STC systems, generally entailing close cooperation with schools in the implementation of

\footnotetext{
${ }^{1}$ This amount was originally appropriated for fiscal years 1994 to 1998 for grants to states and local partnerships under the STWOA (Hershey, et al., 1999).
} 
curriculum changes, partnerships with private business and government bodies, etc. ${ }^{2}$ After its initial five years, the STWOA was not re-authorized. As a result, states face sharp reductions in funding for STC activities. ${ }^{3}$ Given that funding for STC programs is now almost entirely a state (or local) responsibility, state policy-makers will inevitably face the question of whether these programs have been effective in achieving their goals.

Aside from the usual difficulties of judging the success of a government program, an assessment of STC is particularly difficult because the goal is ill-defined. As reflected in the concerns that spurred the STWOA, the goal could perhaps best be characterized as "better career decision making" among young men and women completing their education and entering the labor market. It is difficult to quantify this goal, and even with agreed-upon measures researchers would face challenges given the newness of STC programs and data sets most appropriate for their analysis. Nonetheless, researchers are in a position to begin this task, because new data on STC participation available in the 1997 National Longitudinal Survey of Youth (NLSY97) make it possible to study the impact of STC programs on the early STC transition, as young men and women leave high school and make decisions about employment and higher education.

The goal of this paper is to attempt to uncover evidence on the causal effects of high school STC programs on employment and higher education, taking advantage of the information on STC program participation in the NLSY97 as well as other important features of the data set. In particular, we take seriously the likelihood that individuals select or are selected into participation in STC programs based on characteristics that may be associated with post-high school enrollment or employment, but that may also be unobserved by researchers. While STC is attracting increasing attention from researchers, the existing

\footnotetext{
${ }^{2}$ While "school-to-work" is the more common appellation, many states have adopted the label "school-to-career." Given that most of the effort is devoted to high-school students, and that the goal is to improve career decisionmaking of youths-which may often entail further education-the STC label provides a better characterization. Indeed, in the past school-to-work programs have sometimes suffered from the stigma associated with tracking high-school students into vocational tracks rather than further education (Neumark and Allen, forthcoming). Thus, in this work the "school-to-career" label is used.

${ }^{3}$ For example, in 1996 California won an implementation grant from the National School-to-Work Office. The state received approximately $\$ 130$ million over five years. Following the conclusion of federal funding, the California legislature approved legislation $\$ 5$ million in state funding, which was later cut to $\$ 2$ million by Governor Gray Davis.
} 
work has tended to shy away from trying to draw causal inferences, a conclusion also reached in a recent survey of published academic research on STC across the United States by the Institution on Education and the Economy (Hughes, et al., 2001). In contrast, while not claiming to have the definitive solution to this problem, our goal in this paper is to exploit the NLSY97 to confront this issue in a thorough manner.

Of course, even a causal analysis of the effects of STC on higher education and employment does not lend itself to a full-blown cost-benefit analysis, and indeed given the difficulty of characterizing better career decision making there may never be a complete analysis of this nature. Nonetheless, information on the impact of STC programs on transitions to employment and/or higher education can still inform policy-makers as to whether some of the intended effects of STC are indeed occurring. After all, core concerns of STC are moving people into higher-paying jobs, encouraging skill formation among new labor market entrants, and increasing enrollment or employment in the immediate post-high school period.

Besides addressing the effectiveness of school-to-career, this research relates to broader policy issues. First, there has been an upsurge of interest in both the research and policy community on educational quality, with a focus on establishing test-related standards and studying test-related outcomes. Yet another important perspective on educational quality-not necessarily the most relevant, but perhaps tied in more directly to the extent to which education ultimately affects socioeconomic outcomesconcerns the link between education and labor market success (e.g., Card and Krueger, 1992). STC programs may play an important role in this link. Second, a great deal of research focuses on policies to mitigate the consequences of poverty or attack the sources of poverty, including social programs, income support, and mandating higher wages for low-skill workers. To some extent, though, most policy-makers and researchers would probably agree that the best thing we could do-if we only knew how-is to increase the skills and productivity of those at the bottom of the socioeconomic scale so that they are able to earn a market wage high enough to lift them and their families out of poverty. STC programs are one method to attempt to achieve the goal of raising skills and productivity, perhaps most importantly among those who would not attend four-year colleges. 


\section{$\underline{\text { II. Past Research }}$}

Three types of approaches to assessing the consequences of STC programs have been used in the existing literature. The first relies on evaluations of specific programs, or what might be considered case studies. For the most part, this research has not uncovered compelling evidence of positive effects of STC programs. A 1994 report of the National Center for Research in Vocational Education (NCRVE) provides a thorough compendium of research on these programs (Stern, et al., 1994). Based on this compendium, it is safe to say that there is as yet relatively little persuasive evidence of positive impacts of these programs on adult labor market outcomes. First, few studies have focused on labor market outcomes more than a year or two after completion of the programs. But there is limited evidence that over a period of a few years beneficial effects of some types of STC programs dissipate, as comparison group members find good jobs on their own. Second, many of these studies do not construct a reasonable comparison group, let alone consider the problem of selection into the program on the basis of unobserved characteristics that might also be correlated with outcomes. Third, even those studies that attempt to construct a good comparison group find no beneficial short-term labor market effects, with the possible exception of those students who remained with the employer with whom they "apprenticed" during the program. Finally, some of the evidence suggests that STC programs may discourage postsecondary education.

A national STC study was completed relatively recently by Mathematica Research, Inc. (Hershey, et al., 1999). However, the Mathematica study does not assess the causal relationship between STC and student outcomes, but rather provides a national picture of STC initiatives. The Mathematica study argues that STC implementation "generally involves broad and diverse initiatives that in varied ways touch most or all students, so it is impossible to distinguish between participants and an unaffected comparison group" (Hershey, et al., 1999, p. xviii). As a result, it focuses more on some of the processes involved in STC implementation-important information, but quite different from the focus of this paper.

The second approach to studying STC is indirect, and stems from the argument that STC programs are needed as a means of increasing early job market stability, reducing the costly nature of 
"chaotic" youth labor markets in the United States. The counter-argument to this negative view of the turbulent nature of youth labor markets is that workers receive positive returns to job shopping (e.g., Topel and Ward, 1992), presumably as workers (and employers) learn about their skills, aptitudes, and interests by trying different jobs, leading to increasingly better matches as young workers move through a series of jobs. Thus, this second approach has explored the effects of early labor market stability-which STC programs are supposed to encourage-on adult labor market outcomes.

Earlier research on this question considered the relationship between early job market stability and adult wages by exploring the correlations between a wide range of individuals' youth labor market experiences and their labor market outcomes as more mature adults, in a multivariate framework that controlled for other adult characteristics typically associated with these outcomes (Gardecki and Neumark, 1998). Looking at wages, health and pension benefits, and full-time employment for individuals in their late-20s to mid-30s, the results suggest that these labor market outcomes are for the most part unrelated to the stability of early labor market experiences, especially for men, although as many studies have found, training bestowed longer-term benefits.

However, because unobservables related to match quality and patterns of search and job shopping in the early years in the labor market may be related to measures of early job market stability, this evidence may not reveal the causal effect of early job market stability per se on adult labor market outcomes. Consideration of models of on-the-job search reveals that the bias in the OLS estimates can go in either direction. To remedy this problem, Neumark (2002) uses instrumental variables methods to eliminate endogeneity or heterogeneity bias in the estimated relationship between early job market stability and adult wages. Specifically, time-series and geographical variation in labor market conditions facing workers entering the labor market is used to generate instruments for the job stability experienced by workers as youths. The findings indicate that once account is taken of the endogenous determination of early job stability and adult wages, the evidence points to positive effects of early job stability on adult wages, suggesting that policies that exogenously increase early job stability might have net beneficial effects. However, as this evidence is indirect it is suggestive at best. 
Finally, the third approach to studying STC programs, on which the proposed research builds, is to analyze large-scale longitudinal micro data sets, using statistical research designs intended to uncover the causal impact of STC programs. Although this approach sacrifices some of the richness and institutional detail afforded by case studies, it provides results that are much more generalizable and broadly applicable, allows more precise and more disaggregated analyses by virtue of large sample sizes, and in the case of long panels eventually permits the estimation of effects of STC programs on many aspects of individuals' careers. A critical impediment to research on STC programs using large-scale micro data sets, however, has been the absence of large representative data sets with information on such programs. Fortunately, though, the new NLSY97 offers researchers opportunities to analyze direct evidence on STC programs in the context of a large longitudinal micro data set.

Neumark and Joyce (2001) attempt to evaluate the effects of STC using the first round of the NLSY97, but given the newness of the data set they are restricted to estimating effects on work- and education-related expectations of high-school students. Overall, the evidence in Neumark and Joyce (2000) did not support the finding that there is a causal effect of STC program participation on behavior likely associated with future college attendance-either test taking or the subjective probability of obtaining a four-year college degree. On the other hand, STC program participation does appear to have modest positive effects on educational attainment in terms of respondents' subjective probabilities of obtaining a high-school diploma. Finally, more in accordance with the traditional view of STC programs, the data indicate that participation in these programs increases the perceived likelihood of future labor market activity, both for the year following the survey and at age 30, with effects in the range of two to five percentage points. Regardless, this study is more limited than the present research both in terms of the outcomes it can study, as well as the solutions it considers with respect to the problem of causal inference.

Of course in some respects experimental evidence based on random assignment to STC programs is ideal. To the best of our knowledge, there is no such evidence available for STC programs per se. The only exception is the recent (and ongoing) evaluation of career academies by the Manpower 
Demonstration Research Corporation (Kemple and Snipes, 2000; Kemple, 2001). The most recent results from this evaluation consider students one year after the completion of high school, and find no impact on high school graduation rates, post-secondary education, or employment. While studies of this nature-carefully constructed experiments using random assignment-are in principle the ideal way to evaluate STC programs, such experiments are expensive, extremely difficult to implement, and when they depart from their "ideal" setting are prone to problems identified in the literature on the evaluation of other types of social programs (e.g., Heckman, et al., 2000). For both of these reasons, and because of some of the advantages afforded by secondary longitudinal data, we suspect that examination of the effects of STC based on longitudinal micro-data sets will ultimately play an important role in assessing the effectiveness of STC programs.

\section{Estimating the Causal Effects of STC Using the NLSY97}

The core empirical framework will be estimation, at the individual level, of the relationship between employment and/or enrollment in the post-high-school period, and participation in STC. ${ }^{4}$ STC participation will be categorized in terms of participation in specific types of programs discussed below. The analysis is based on dichotomous choice models for employment and enrollment. ${ }^{5}$ Generically, let $\mathrm{Y}_{\mathrm{ij}}$ be an indicator equal to one for when individual $\mathrm{i}$ in school $\mathrm{j}$ is employed or enrolled (depending on the analysis), let $\mathrm{STC}_{\mathrm{ij}}$ be a dummy variable for whether the individual reports participating in an STC program (a vector of dummy variables for participation in a variety of STC programs is used in the empirical implementation), and let $\mathrm{X}_{\mathrm{ij}}$ be a vector of controls that at times will include both individual and school characteristics. We estimate linear probability models for $Y_{i j}$ as a linear function of these variables:

\footnotetext{
${ }^{4}$ We considered studying other outcomes, including criminal activity, single parenthood, part-time vs. full-time employment, type of post-secondary education, etc. But the combination of lower incidence of these different or more detailed outcomes, and participation rates of about 10 to 20 percent in most types of STC programs, precluded obtaining sufficiently precise estimates in these other analyses.

${ }^{5}$ Those who report their employer as the military are coded as employed.
} 


$$
\mathrm{Y}_{\mathrm{ij}}=\alpha+\beta \mathrm{STC}_{\mathrm{ij}}+\mathrm{X}_{\mathrm{ij} \gamma} \gamma+\varepsilon_{\mathrm{ij}}{ }^{6}
$$

The parameters of interest are $\beta$, of course, with estimates of $\beta$ denoted $b$. Consistent estimation of $\beta$ requires that $\varepsilon_{\mathrm{ij}}$ be uncorrelated with the controls in $\mathrm{X}_{\mathrm{ij}}$ as well as with $\mathrm{STC}_{\mathrm{ij}}$. However, as in most research on program evaluation, the core problem that this research has to confront is "endogenous selection." The researcher can identify individuals who participate in STC programs, and can measure outcomes hypothesized to be related to this participation. But because individuals choose to participate in the program, it is difficult to establish whether an empirical relationship between program participation and an outcome is a result of the program, or instead simply reflects individuals more disposed toward a particular outcome having participated in the program. For example, individuals with the highest expectations of work after high school may choose to participate in STC programs, perhaps because they are more interested in learning about the job market. When actual work behavior is observed, then, we would find that those who participated in STC have higher employment rates. Yet in this example there is a non-causal source of the positive relationship between STC and employment. Alternatively, schools with student populations that tend not to go to college may be more likely to offer STC programs and hence have both higher participation and higher post-secondary employment (and lower college enrollment). In either case $\mathrm{STC}_{\mathrm{ij}}$ is correlated with $\varepsilon_{\mathrm{ij}}$, so that $b$ is a biased estimate of the causal effect of STC programs. Formally, while equation (1) may be the model we can estimate, the true model for an individual observation is

$$
\mathrm{Y}_{\mathrm{ij}}=\alpha+\beta \mathrm{STC}_{\mathrm{ij}}+\mathrm{X}_{\mathrm{ij}} \gamma+\mathrm{q}_{\mathrm{i}}+\mathrm{v}_{\mathrm{ij}} \text {, }
$$

where $\mathrm{q}$ is an unobservable, fixed over time for each individual, reflecting underlying factors influencing post-high school enrollment and employment decisions and outcomes, so that the error term $\varepsilon$ in equation

\footnotetext{
${ }^{6}$ We estimated versions of all models reported in this paper using logit models as well, and the results were very similar. Using the linear probability model simplifies the presentation, and avoids distributional assumptions that underlie the logit model. Reported standard errors are robust to heteroscedasticity. Also, because there are often multiple observations on students within the same school, the reported standard errors allow for heteroscedasticity of the error term across schools and non-independence of an arbitrary nature within schools, which typically results in somewhat larger standard errors.
} 
(1) reflects both $q$ and an idiosyncratic error term $v$. The assumption is that $\mathrm{E}(\mathrm{v} \mid \mathrm{STC}, \mathrm{X}, \mathrm{q})=0$, but because of selection into STC based on $\mathrm{q}, \mathrm{E}(\varepsilon \mid \mathrm{STC}, \mathrm{X}) \neq 0$.

The most common approach to the endogenous selection problem generally, which is typically made possible by the existence of large-scale longitudinal data sets, is to implement a panel data estimator. Such estimators provide a measure of the outcome of interest before and after program participation, so that the measure before the intervention captures the unobserved individual characteristics that might be associated with program participation, and the change in the outcome then provides a causal estimate. However, there is a fundamental difficulty that precludes longitudinal estimation in studying the effects of STC. In particular, because we are studying the effects of a program on individuals' first labor market experiences (with the exception, perhaps, of some work while in high school), or on further school enrollment of those already enrolled, there are no meaningful observations on the outcomes of interest prior to the program.

As a result, in this research we have to consider other methods. Each of these is subject to some criticisms-but indeed the same can be said of social experiments and longitudinal estimation (in other contexts). The hope is that the "collage" of evidence from the alternative approaches, along with some analysis of whether each approach is likely to lessen any biases rather than exacerbate them, will help provide a range of causal estimates of the effects of STC.

The first line of defense against unobserved heterogeneity is to try to introduce an extensive set of controls for the factors that might affect the dependent variables-in this case post-high school enrollment and employment-and also be correlated with STC participation. In principle, this may include direct measures of such factors, or proxy variables for unobservable factors, which we denote Z. Because proxy variables figure prominently in our analysis, including what might be considered a set of ideal proxies, we discuss the conditions under which a proxy variable corrects for the unobservable in some detail. Wooldridge (2002) discusses the two conditions under which inclusion of proxy variables for unobserved factors leads to consistent estimates of the other parameters of interest. The first condition is that $\mathrm{Z}$ is redundant in the equation of interest, or equivalently $\mathrm{E}(\mathrm{Y} \mid \mathrm{STC}, \mathrm{X}, \mathrm{q})=\mathrm{E}(\mathrm{Y} \mid \mathrm{STC}, \mathrm{X}, \mathrm{Z}, \mathrm{q})$. This is not a 
controversial assumption, as the only reason we include $\mathrm{Z}$ is because we do not have a measure of $\mathrm{q}$. The second condition is that if we take the linear projection of $\mathrm{q}$ on $\mathrm{Z}$, and define the projection error as $\eta$, then $\eta$ is uncorrelated with STC and each of the variables in X. In words, this requires that the proxy $Z$ is sufficiently closely related to the unobservable q that once $\mathrm{Z}$ is included in equation (2) there is no omitted variable bias in the estimated coefficients of STC and X from the variation in $\mathrm{q}$ that is not reflected in the linear projection of q on $\mathrm{Z}^{7}$

Wooldridge terms the case when the second condition does not hold exactly as an "imperfect proxy," and shows that the inclusion of such a proxy is still likely to reduce bias in the OLS estimates as long as the proxy is reasonable. Of course, one can never know with certainty that a given set of proxy variables adequately captures the unobservables that underlie the endogenous selection problem. But comparing the estimates of the coefficients of STC participation using a narrow set of control variables and a detailed set of proxy variables can help to gauge whether biases from remaining unobservables are likely. Specifically, if the inclusion of the detailed proxy variables has little or no impact on the estimates, then because their inclusion reduces the bias, it is arguably less plausible (more so the more complete the set of proxy variables) that remaining unobservables generate a correlation between STC participation and enrollment or employment.

The NLSY97 offers a detailed set of control variables for characteristics of both the individual respondents and their families. In addition to fairly typical demographic controls (sex, race, ethnicity, and age), the data set includes three additional sets of control variables that we view as potentially important. These include data on: living arrangements and the respondent's family (including urban residence, whether one lives with both biological parents, only the biological mother or father, a biological parent and a step parent, or in some other arrangement, as well as information on household size, household

\footnotetext{
${ }^{7}$ Note that this implies that, in contrast to the classical measurement error case where we would postulate the relationship between the unobservable $q$ and the "error-ridden" proxy $Z$ as $Z=\theta q+\mu$, with $\mu$ uncorrelated with $q$, we instead use $\mathrm{q}=\lambda+Z \pi+\mu^{\prime}$, where $\mu^{\prime}$ ' is uncorrelated with $\mathrm{Z}$. Then when $\mu^{\prime}$ ' appears in the estimated equation, unlike in the classical measurement error case it does not lead to inconsistent estimates because of a correlation with Z.
} 
income, ${ }^{8}$ and the biological mother's schooling); test scores from the Armed Services Vocational Aptitude Battery (ASVAB); and self-reported measures of school behavior (whether the respondent was threatened at school, or had gotten into a physical fight at school, and whether the respondent had been late with no excuse two or more times, or absent two or more weeks, all measured in 1997). This rich array of variables seems likely to capture some of the variation in underlying propensities for post-high school enrollment or employment, including the quality and quantity of human capital investments in children, resources available in the household, educational norms in the family, labor market networks, the individual respondents' academic ability, and the extent to which the respondent is learning traits such as timeliness and reliability that are valued by employers. But these variables may also directly affect enrollment and employment outcomes, so they perhaps should not viewed as proxy variables.

Aside from a rich set of controls, the NLSY97 data have a second feature that is potentially very useful in trying to uncover the causal effects of STC. Specifically, the NLSY97 also includes the respondent's self-reported subjective probabilities for future education and employment, including: receipt of a high school diploma by age 20; obtaining a four-year college degree by age 30; and working over 20 hours per week at age 30. As explained in more detail in the next section, these variables are measured in 1997, before the STC participation that is used in the estimation. By including these work and schooling expectations, we have in mind the following "experiment." Prior to participating in STC, students are asked about their post-high school work and schooling expectations. Then some participate in STC and some do not, and we subsequently observe some dimensions of their post-high school work and schooling behavior. If, for example, conditional on educational expectations, STC participants are more likely to be enrolled in college after leaving high school, then it might be quite sensible to infer a causal effect of STC, because the expectations questions should have controlled for remaining unobservables associated with post-high school educational decisions or outcomes.

\footnotetext{
${ }^{8}$ Household income is from Round 1 , and is from the parent questionnaire except in the rare event that the youth is defined as independent in 1997.
} 
These expectations data can be thought of in two alternative ways that may help justify their use. First, the expectations variables can be thought of as coming closer to serving as perfect proxy variables. They should easily satisfy the redundancy condition because they should play no independent role net of the unobserved propensities for post-high school enrollment and employment for which they are proxies. And they should satisfy the second condition for a proxy, because it seems very likely that once these are included, there should not be any remaining correlation between the unobservable q in equation (2) and STC (or X). Indeed, we can think of any remaining variation in q net of these expectations (or the error term $\eta$ in the linear projection of $q$ on these expectations) as nothing but forecast error. In this case $\eta$ would be uncorrelated with X and any variation in STC that could have been predicted at the time the expectations were formed, which is the variation that gives rise to endogenous selection. An exception to this would be if assignment to STC programs is based on information about $\eta$ that is unknown to the individual, which could occur if schools have better information about factors leading to benefits from STC than students have and assign students to STC based on this. But as long as STC participation is chosen by students, the earlier school and work expectations may be ideal proxies.

Alternatively, including the expectations questions can be interpreted as coming closer to the longitudinal estimator that we would like to have, but which-as explained above-does not exist in the study of STC. That is, these latter controls are meant to capture some measures of an individual's propensity for later enrollment or employment prior to participation in STC, and in that sense, perhaps, can be interpreted as proxies for the unobserved lagged behavior that is in some cases included as an independent variable to address the problem of endogenous selection. The tradeoff, however, is that these variables may to some extent be outcomes of the high school experience, including STC. Although most of our specifications rely on STC participation measured after these behaviors and expectations are measured, the STC participation may be related to earlier features of respondents' high school education. If so, then a finding that including these behaviors and expectations variables reduces or eliminates the effects of STC might reflect "over-controlling" that leads to understatement of the effects of STC because we have effectively included a version of the dependent variable as an independent variable. But 
conversely, if the effects of STC persist upon including these variables, we would argue that a causal interpretation of the effects of STC would be significantly bolstered.

The methods discussed thus far focus on trying to control "directly" for the individual-level heterogeneity that may underlie endogenous selection of individuals into STC participation, by including one version or another of controls for this heterogeneity. The alternative way to approach the selection problem is to indirectly avoid the bias caused by this unobserved heterogeneity, using an instrumental variable (IV) that helps predict participation in STC, but is not itself correlated with the unobserved factors associated with this participation that also affect enrollment and employment outcomes. This is particularly useful if despite the availability of the proxy variables and the expectations data there is still substantial selection on individual-specific unobservables. In this case equation (1) is augmented with an equation for the propensity to participate in STC, in which Z denotes the instrumental variable:

$$
\mathrm{STC}_{\mathrm{ij}}=\alpha^{\prime}+\beta^{\prime} \mathrm{Z}_{\mathrm{ij}}+\lambda_{\mathrm{ij}} .
$$

In the NLSY97, in addition to the survey questions administered to individuals, a survey of schools elicits information on STC programs offered by schools; these data are accessible only to BLS researchers. ${ }^{9}$ The school-level information on offerings of STC programs raises the possibility of using school-level variation in STC programs to address the selection problem. In particular, under some assumptions these school offerings could provide instrumental variables to use in accounting for the endogenous selection of individuals into STC programs. School offerings of STC programs would provide a reasonable IV for individual participation if two conditions hold. First, these offerings should influence individual participation. And second, the expectation of $\mathrm{Y}$ in equation (1) conditional on $\mathrm{X}$ and STC participation should not depend on whether the school offers STC programs.

\footnotetext{
${ }^{9}$ For the most part, the school survey asks about the same programs covered in the individual survey, with a few exceptions. First, the individual survey also includes information on "career major" programs, which are a sequence of courses based on an occupational goal. However, information on these programs is elicited in a different manner from the questions used for other school-to-work programs, and hence is not analyzed here. (In the school survey, in contrast, information on all types of school-to-work programs comes from a similar set of questions.) Second, on the school survey apprenticeships and internships are covered separately. Third, the school survey does not cover mentoring programs. And finally, there is an "other" category for STC programs, which we ignore in our analysis.
} 
A priori, it seems likely that the first condition would hold. However, in earlier work (Neumark and Joyce, 2000) this IV strategy was considered in estimating equations for expected employment and enrollment behavior, and, surprisingly, there turned out to be virtually no correspondence between the STC programs in which students reported participation, and school reports of provision of STC programs. In particular, overall and by type of program, individual and school reports were generally statistically independent. ${ }^{10}$ But whereas the earlier research was based on the 1996 school survey, data from a new 2000 school survey are now available, and the newer survey collected data in a more reliable fashion that should increase the correspondence between individual and school reports regarding STC. In particular, the 1996 survey used a grid structure to elicit information from schools on STC programs. The grid had some confusing features, which may well explain why there was an item non-response rate averaging approximately 15 percent. In contrast, the 2000 survey was redesigned, although eliciting largely the same information, and has an item non-response rate averaging only 2.3 percent. ${ }^{11}$ It turns out that the STC offerings in the 2000 school survey have much higher predictive power for individual participation. Most importantly, in first-stage regressions for STC program participation (based on the specifications used later in the paper) the estimated coefficient on whether the school offers the corresponding program is always positive and significant at the one-percent level, with F-statistics for the instruments in the firststage regression (which with a single instrument are the squares of the t-statistics on the instrument) often exceeding 10. At the same time, though, we still find that there is a good deal of slippage between individual reports of participation and school offerings, as it is quite common for individuals to report participation in programs that their schools do not report offering, which would appear to be impossible.

\footnotetext{
${ }^{10}$ In working more with these data, we uncovered some errors in use of the school survey data in Neumark and Joyce (2000), in that some schools that did not respond to the survey were inadvertently treated as offering no STC programs. However-reinforcing the poor correspondence between the individual and school data-when these schools were dropped the association between individual and school reports of STC programs weakened rather than strengthened.

${ }^{11}$ In addition, although likely less important, whereas Neumark and Joyce (2000) used self-reported STC participation from Round 1, this paper uses data from Rounds 2-4. In Rounds 2-4 the questions in the individual survey refer to current participation (specifically, participation since the last survey), rather than whether one ever participated, which should increase the correspondence of the answers from the individual and school surveys.
} 
However, it is the second condition-that the IV can be excluded from the employment or enrollment equation we are estimating-that appears to be most problematic. It is easiest to illustrate the problem by first considering the ideal case. The ideal case is one in which school offerings of STC programs are randomly distributed across schools. In this case it might still be possible to tell a story in which STC offerings affect enrollment and employment even conditional on individual participation. For example, if a school offers extensive STC programs even non-participants might be affected, perhaps because of the influence of peers or the overall culture of the school. But when STC programs are not randomly distributed across schools the problem could be far worse. If, for example, STC programs tend to arise in schools that are failing to send students to college, or schools that fail to place students in jobs, then these offerings may turn out to be strongly correlated with the error term in equation (1).

It turns out to be readily apparent in these data that STC program offerings are strongly associated with school-level characteristics that may be associated with students' post-secondary enrollment and employment. In Table 1, we report estimates of linear probability models for the STC programs that each individual is offered in his or her school, first for participation in any program, and then in each specific type of program. The independent variables are a number of school-level characteristics reported on the same school survey described above. Because this analysis is intended to be informative about the possibility of estimating equation (1) using instrumental variables, the sample here is the subsample of the main analysis sample in this paper (described in more detail below) for which individuals can be matched to the school survey, and hence for which the instruments are available.

Inspection of Table 1 shows that many school-level characteristics that are likely to be associated with post-high school outcomes are also strongly associated with STC offerings. ${ }^{12}$ For example, the proportions of students involved in four types of problematic behavior-truancy, pregnancies, alcohol

\footnotetext{
${ }^{12}$ We report coefficients for the regressions including the school-level characteristics only. But because the more appropriate question for IV estimation might be whether STC offerings are associated with school-level characteristics after controlling for the characteristics of individual respondents, we also report on the statistical significance of the results if we include all of the individual-level controls as well, using the '+' superscripts. (Specifically, we include the controls listed in Table 4.) As indicated by the '*' and '+' superscripts in the table, this has virtually no impact on the conclusions.
} 
possession, and drugs-are in many cases significantly related to school STC offerings. The directions of the effects are not always consistent, but the estimates overall indicate that characteristics of the student body are associated with STC programs students are offered. Teacher characteristics are also strongly associated with STC offerings. In particular, students in schools with highly paid teachers are significantly less likely to be offered many types of STC programs.

Although less relevant for assessing whether we can use the school-level variation in offerings of STC as an IV, Table 2 reports estimates of the same specifications reported in Table 1, but simply using all of the school survey observations available in the NLSY97, weighted for representativeness of the sample of schools. While the statistical strength of the relationships between school and student-body characteristics and STC offering is somewhat weaker, the estimates are often quite similar, and many are statistically significant. While not as directly informative about the potential for using IV estimation, these estimates are informative about the simpler question of the types of schools that offer STC programs.

Based on these findings, as well as the still problematic relationship between school STC offerings and individual STC participation noted above, we do not put any store in IV estimation based on the STC programs offered by schools. STC programs are sufficiently strongly associated with characteristics of schools and their students that the school-level variation is not helpful in identifying the effects of STC participation. Another way to think about the same problem is as follows. A simple way to examine the question of whether STC programs increase post-high school education or employment is to look directly at school-level estimates of these post-high school outcomes as functions of the STC programs that schools offer. Such regressions would be easily interpreted from a policy perspective, as they attempt to ask whether getting more STC programs to be offered by schools increases post-high school enrollment or employment. However, these regressions only answer this question if the observed variation in school STC offerings is not correlated with the error terms in these "reduced-form" equations. Thus, for example, if STC programs tend to proliferate in under-performing schools, this would tend to obscure beneficial effects of STC in the across-school "experiment." The evidence in Table 1 suggests 
that, in fact, variation in offerings of STC programs at the school level is strongly associated with characteristics of schools that are likely to be strongly related to post-high school outcomes for their students. We therefore do not pursue this strategy of estimating the effects of STC participation based on school-level variation in offerings of STC.

The preceding estimates illustrate that there are important school-level characteristics of the student body and the school itself that are associated with whether STC programs are offered. These associations suggest that if we use individual-level STC participation to identify the effects of STC, but the variation in participation stems partly from variation across schools, then we may obtain biased estimates. That is, $\varepsilon$ in equation (1) may have a school-level component that is correlated with individual STC participation. It turns out that the NLSY97 has one additional feature that we can exploit to address this problem. Specifically, there are data on multiple students in the same school. This occurs because the NLSY97 consists of multi-stage stratified random samples (a cross-section sample and a supplemental sample of additional blacks and Hispanics); ${ }^{13}$ the multi-stage stratification leads to observations that tend to be clustered by geographic areas. All schools in the sampling units were identified and assigned a unique code. While these codes are not included in the public-use files, they are available to BLS researchers. Because of this feature, school fixed effects can be added to equation (1) to control for all unobserved factors that are common to students within a school. The school fixed-effects estimator identifies the effects of STC participation from the within-school differences between those who do and do not participate in STC and the differences in outcomes associated with this participation, and hence does not rely at all on variation in STC participation that may be driven by the problematic across-school variation in offerings of STC.

In other words, even though schools that offer STC differ from other schools, so that we cannot identify the effects of STC from across-school variation, the NLSY97 data permit us to look within schools, estimating the effects of STC solely from within-school variation in STC. Of course, since

\footnotetext{
${ }^{13}$ In the data, anyone of Hispanic origin is coded as Hispanic, and blacks must be non-Hispanic.
} 
individuals within schools differ from one another, in the within-school estimation attention must still be paid to individual-level heterogeneity.

\section{$\underline{\text { IV. Data Set, Variables, and Analysis Sample }}$}

The research relies on the 1997 National Longitudinal Survey of Youth (NLSY97), which offers the best information available to researchers to date on STC programs. In the NLSY97 individuals are surveyed about "programs schools offer to help students prepare for the world of work." The STC programs covered in the NLSY97 include: job shadowing; mentoring (matching students to an individual in an occupation); cooperative education (combining academic and vocational studies); work in a schoolsponsored enterprise; tech prep (a planned program of study with a defined career focus); and internships or apprenticeships.

In Round 1, the STC questions cover the types of programs in which individuals participated (at all and most recently), whereas in subsequent rounds the questions shifted to participation in the past year. The questions are asked of all $9^{\text {th }}$ to $12^{\text {th }}$ graders in Round 1. In Rounds 2-4 they are asked of any respondents enrolled in school (including college), although we focus on participation while in high school by only using STC information for years in which respondents were enrolled in high school.

The manner in which the STC data are collected raises two issues. First, because some (and most likely the larger share of) STC participation occurs in the later high school years, we cannot use the NLSY97 to study the effects of STC on high school completion. Because high school dropouts would by construction report less STC participation, there would be a spurious negative correlation between STC participation and dropping out of high school. Second, a moderate share of individuals report some college enrollment in the last year in which they are enrolled in high school, so in principle these individuals could be reporting STC during their short initial spell of college. As a check on the robustness of our results, we excluded the STC information for that interview year when calculating our STC measures. We found that our qualitative conclusions were unaffected by this alteration in the STC measure. 
The analysis is based on data from the first four rounds of the NLSY97. When the first round was administered, in 1997, respondents were aged $12-17 .{ }^{14}$ With the second round, then, we can begin to observe some respondents who have left high school, but we get many more such observations with the third and fourth rounds, and therefore focus on educational and employment outcomes measured as of the third or fourth rounds. Table 3 gives some idea of the breakdown of the sample. First, with respect to the basic sample, of the total 8,984 original respondents to the NLSY, 8,510 were interviewed in 1999 or 2000 (Rounds 3 and 4 ). ${ }^{15}$ Of these, attention will be restricted to those aged 18 or older, which eliminates about 40 percent of the sample (about 3,500 observations), and to those for whom we get at least one observation (in 1999 or 2000) at which they are not enrolled in high school, yielding 4,234 observations. The sample is restricted in this way to isolate those individuals for whom we can observe the early years of their employment or higher education after leaving high school. In future research we will study the longer-term career trajectories of STC participants and non-participants.

In addition to meeting these criteria, information on STC participation is also required. In order to get an accurate reading on STC participation, and to be able to measure some behaviors and expectations as of a well-defined date prior to the STC participation we study, we focus mainly on the information provided in the surveys after the first round in 1997, which for each subsequent round covers participation in the past year. (However, we verified the robustness of the results to using information on any STC in which the respondent had ever participated.) Requiring STC information after Round 1 drops sample observations for those who did not answer the STC part of the survey after this round, either because they had not spent time in high school in 1997 or a subsequent year, or in subsequent years were not enrolled as of the interview date and hence were not asked the STC questions. Coupled with some

\footnotetext{
${ }^{14}$ Respondents were aged 12-16 as of December 31, 1996.

${ }^{15}$ Like any longitudinal study, the NLSY97 suffers from some attrition, as indicated by the dropoff in interviews. In general, though, the National Longitudinal Surveys have been very successful at following cohort members over time. It is quite plausible that attriters differ from non-attriters with respect to their STC transitions - for example, those who become idle after leaving high school may be more like to attrit. However, only if attriters differ from non-attriters with respect to the effects of school-to-work will the parameter estimates of interest be biased. This question can be explored using methods paralleling those in Falaris and Peters (1998), who test for attrition bias by comparing estimates of behavioral equations of "eventual" attriters and non-attriters in the period prior to attrition of the former. However, this will not be feasible with the NLSY97 until quite a few more rounds of data are available.
} 
final sample restrictions on availability of the other data used in the study, this takes us down to 3,279 observations. For our baseline analysis sample, we also exclude private schools, which are not the focus of STC policy, and vocational schools, which in a sense offer nothing but STC. This leaves us with 2,933 observations.

Finally, for two of the analyses the sample is restricted further. First, while one can estimate linear models with school fixed effects for the full sample, observations that are "singletons" in their school contribute no identifying information, so there is some interest in comparing estimates with and without the fixed effects for the subsample of individuals for which there are multiple respondents for their school; there are 2,230 such observations. Second, the work and schooling expectations data from 1997 are only asked of those born in 1980 or 1981, the two oldest birth cohorts, leaving us with 2,057 observations from the baseline analysis sample; we lose far fewer than a proportionate number of observations because the other sample restrictions leave us with mainly older NLSY97 respondents. $\underline{\text { V. Results }}$

\section{STC Participation}

We begin by presenting some linear probability models for who participates in STC, in part to provide descriptive information on STC participation, and in part to provide a preliminary assessment of the severity of the problem of endogenous selection into STC programs. Table 4 presents in the first row the proportions of students participating in any STC and then in each type of program covered in the individual survey, and in the remaining rows presents the linear probability estimates for any STC participation and participation in each type of program. The models include the demographic controls, the living arrangement/family controls, and the test scores and school behaviors that are used as proxy variables for unobserved heterogeneity.

One curious finding is that for three types of STC programs (coop, school enterprise, and tech prep) black students are significantly more likely to participate, with the estimates indicating participation probabilities that are higher by 32 to 79 percent relative to the overall sample. Note that this appears to be a within-school phenomenon, as there was no significant evidence in Tables 1 or 2 that schools with more 
black students were more likely to offer STC. Whether this reflects higher returns to STC for blacks is addressed below; the alternative is that blacks for some reason are more likely assigned to such programs despite no greater benefit for them, which would raise a number of interesting questions that are not the focus of this paper.

The most striking finding, though, which is more directly relevant to the question of whether and how we can estimate the causal effects of STC participation, is that almost no other variables are significantly related to STC participation, aside from what might be considered a smattering of the estimated coefficients the statistical significance of which could just reflect randomness; indeed, excepting the estimates of the black-white difference, 7.5 percent of the remaining coefficient estimates are significant at the five-percent level. This is also reflected in the very low R-squares for these models of individual participation, which are generally one-fifth or less of the R-squares for the models for whether schools offered STC, even when individual characteristics were omitted from those models (Table 1). The finding that very few variables predict STC participation suggests that problems from endogenous selection into STC participation may not be too severe. If STC participation were randomly assigned we would, of course, expect none of the variables in Table 4 to predict participation, and the evidence does not deviate from this too strongly. Nonetheless, because STC participation was not randomly assigned, selection on unobservables of course cannot be ruled out.

\section{Basic Multivariate Analysis}

Tables $5 \mathrm{~A}$ and $5 \mathrm{~B}$ begin the multivariate analysis. While Table $5 \mathrm{~A}$ reports the estimated coefficients of the variables for participation in STC programs, Table 5B reports estimated coefficients for the control or proxy variables for the specifications including the full sets of proxy variables. Turning first to Table 5A, the first four columns report linear probability estimates of models for whether the individual has some college education since leaving high school, and the last four columns report models for current employment. For each of the two dependent variables, the first column includes only the demographic controls. The second through fourth columns include an increasingly larger set of the 
control or proxy variables: first adding the living arrangement/family variables, then the test scores, and finally the school behaviors. ${ }^{16}$

Looking first at college education, the estimates in Table 5A reveal considerable heterogeneity in the effects of different types of STC programs. In column (1), with minimal controls, we see that mentoring and school enterprise STC programs are associated with a significantly higher likelihood of some college education, with the differential ranging from about 0.07 to 0.11 . Relative to the sample proportion of 0.50 with some college, these estimates imply increases of 14 to 22 percent in the probability of college attendance. On the other hand, tech prep STC programs are associated with a significantly lower likelihood of college education.

In columns (2)-(4), as the control variables are added, these estimated effects weaken in size and statistical significance although overall the changes are small. ${ }^{17}$ Adding the controls for living arrangements and family structure, the estimated effects of school enterprise and tech prep fall slightly and remain statistically significant (the latter only at the ten-percent level), while the estimated effect of mentoring falls by about one-third and becomes statistically insignificant. This latter result reflects the finding that those with non-traditional family structure are less likely to be in mentoring programs (Table 4), and, as shown in column (1) of Table 5B, are less likely to attend college, so that absent these controls the omitted variable bias is positive. When the ASVAB scores are added, in column (3) of Table 5A, the estimated effects of school enterprise and tech prep fall further, although the former remains statistically significant. At the same time, the estimated effect of job shadowing rises and becomes statistically significant at the ten-percent level, presumably reflecting the negative association of all four test scores with participation in job shadowing (Table 4), and the positive associations between test scores and college attendance (Table 5B, column (1)). Finally, when the school behaviors are also added, we find

\footnotetext{
${ }^{16}$ The variables included in each of these sets of controls are listed in Table 4.

${ }^{17}$ We use the word "effect" to summarize our results once we include the proxy variables, as this represents our first strategy to recover causal effects. We are well aware, of course, that each strategy may not in fact reveal causal effects.
} 
that only school enterprise STC programs are significantly associated with college attendance, with a positive effect estimated at 0.088 .

Columns (1')-(4') turn to current employment. The results for current employment are less sensitive to the addition of the proxy variables than were the results for some college. In all cases we find statistically significant positive effects of coop and internship/apprenticeship STC programs, with effects near 0.07 . Relative to a sample proportion currently employed of 0.64 , these estimates imply that these types of STC programs are associated with approximately 11 percent increases in the probability of posthigh school employment.

The estimates of the coefficients of all of the control (and proxy) variables in the fullest specifications are reported in Table 5B. Aside from the findings already noted, there are a few other noteworthy results, most unsurprising. First, women and blacks are significantly more likely to have attended some college, conditional on the observables, while blacks are less likely to be employed. In general, household structures deviating from two biological parents are associated with a lower likelihood of college attendance and a higher likelihood of employment, while respondents from smaller households, from households with higher income, and whose mothers are more educated are more likely to have attended some college. Presumably all of these effects reflect the impact of economic resources on college attendance. Also not surprisingly, the ASVAB scores-in particular for word knowledge and math knowledge-are significantly positively associated with college attendance, but not with current employment. Finally, all four indicators of troublesome behaviors in high school are significantly associated with a lower probability of attending college. Thus, the proxy variables have rather strong effects, and in the expected directions, on the enrollment and employment outcomes, suggesting that the reason they do relatively little to mediate the effects of STC participation is because they are very weakly associated with this participation-as documented in Table 4-rather than because they are uninformative about enrollment and employment outcomes.

Overall, the basic multivariate analysis suggests some positive effects of STC participation on college education and on current employment. More specifically, school enterprise programs are 
associated with a higher likelihood of obtaining some college education, and coop and internship/apprenticeship programs are associated with increased employment. As already noted, the extensive set of proxy variables does relatively little to alter the estimated relationships between STC and enrollment and employment, although there may still be important unobservables underlying these estimated effects. In particular, although the links between coop or internship/apprenticeship programs and later employment seem reasonably straightforward, the link between school enterprise and college attainment is less obvious, suggesting that the estimated effect of school enterprise programs may be spurious and reflect underlying differences in unobservables rather than effects of STC participation. In the following subsections such questions receive more attention.

\section{Work and Schooling Expectations}

The next analysis introduces variables measuring respondents' work and schooling expectations during high school. Recall that these are measured in 1997, prior to when STC participation is measured. Thus, the hope is that these variables capture unobserved characteristics of respondents associated with the dependent variables, without themselves being driven by STC participation. Further, these variables are intended to "mimic" a longitudinal before-and-after estimator by asking whether observed work and schooling behavior differs from earlier expectations in a manner that suggests an effect of STC participation.

The results are reported in Table 6. For each dependent variable, we first report the estimates excluding these variables (and hence paralleling columns (4) and (4') of Table 5) for the subsample of observations-the 1980 and 1981 birth cohorts-for which these data are available. Holding the sample constant allows us to isolate the effects of adding the expectations variables. The estimates for this subsample in columns (1) and (1') of Table 6 are generally similar to the corresponding estimates for the full analysis sample. For some college, only for school enterprise STC programs is there a significant effect of STC. It is positive like for the full sample, although a bit larger (0.113 compared with 0.088). For current employment, the estimated effect of internship/apprenticeship programs is the same (0.072), 
and remains statistically significant for the subsample. However, the estimated effect of coop programs falls somewhat (from 0.071 to 0.047 ) and is no longer statistically significant.

Columns (2) and (2') report the results when the expectations variables are added. There is remarkably little change in the estimated coefficients or their statistical significance. The estimated effect of school enterprise on college attendance falls by 0.009 and remains statistically significant, and the estimated effect of internship/apprenticeship programs is unchanged. ${ }^{18}$ Furthermore, none of the magnitudes of the estimated coefficients of the other STC programs change much or become statistically significant. Finally, we note that the expectations for a four-year degree are strongly positively associated with actual college attendance. At the same time, these expectations are strongly negatively associated with employment, whereas work expectations for age 30 are strongly positively associated with employment. This latter evidence indicates that the expectations variables are quite informative about subsequent behavior, bolstering the validity of this approach.

Thus, it appears that once we include the detailed set of control variables (in the last columns of Table 5A), this analysis points to little remaining selection bias in the estimated effects of STC. While the analysis with the expectations data could only be done on a subsample, we can take the finding of no indication of remaining bias and return to the estimates for the full sample. The evidence, therefore, still points to positive causal effects of school enterprise STC programs on college attendance, and of coop and internship/apprenticeship programs on employment, in the immediate post-high school period.

\section{School Fixed Effects}

Finally, we turn to the analysis incorporating the fixed school effects, to avoid any identification of the effects of STC participation driven by across-school variation. For this analysis, we restrict attention to the subsample of individuals with multiple observations in the same school, as it is only these individuals who identify the effects of STC programs; any variation for individuals who are the sole representatives of their school are captured in the fixed effect for their school. We first report estimates

\footnotetext{
${ }^{18}$ This evidence also indicates that concerns regarding "over-controlling" were clearly not warranted, as the inclusion of the variables measuring expectations (and behaviors, in Table 5) has relatively little impact on the estimates.
} 
without the school fixed effects for this subsample, and then with the fixed effects. Of course, the fixed effects estimates would be identical if the "school singletons" were included, albeit with different standard errors, so we can still do the comparison to the full sample estimates without fixed effects. ${ }^{19}$ In these specifications we include the full set of proxies, but we exclude the expectations variables because they did not matter in Table 6, and because this would impose a further sizable sample restriction.

The estimates in columns (1) and (1') of Table 7, for the "fixed effects sample" but excluding the fixed effects are quite similar to the full sample results (columns (4) and (4') of Table 5A). There is a positive and significant estimated effect of school enterprise on college attendance that is only a shade larger (0.091 versus 0.088$)$, and positive and significant estimates of the effects of coop and internship/apprenticeship programs on current employment. However, while the estimated effect of coop programs is of similar magnitude, the estimated effect of internship/apprenticeship programs is larger (0.123 versus 0.072$)$. In addition, the estimated effect of tech prep programs on college attendance is larger negative $(-0.070$ versus -0.042$)$ and statistically significant.

The important question, though, is how the estimates change when the school fixed effects are added. In the estimates for college attendance, the effects of STC programs strengthen, with the already significant effects of school enterprise and tech prep programs growing, and a positive and significant effect of job shadowing programs emerging as well. In the estimates for current employment, the estimated positive effect of coop programs grows from 0.073 to 0.089 , remaining statistically significant, while the estimated effect of internship/apprenticeship programs falls from 0.123 to 0.072 , and becomes statistically significant only at the ten-percent level. The changes in the estimated effects of STC program participation are not large, but they are not trivial either, and in some cases the conclusions are substantively different (e.g., with respect to job shadowing). Hausman tests for whether we need the school fixed effects (relative to random effects) yield p-values of 0.19 for the some college specification, and 0.25 for the current employment specification. Formally these results suggest that we can exclude the

\footnotetext{
${ }^{19}$ If observations on individuals who are the only sample member from their school are included the standard errors are larger.
} 
school fixed effects. But these p-values are nonetheless relatively low, and the standard errors increase very little in the fixed effects estimation-in contrast to what occurs in many applications. Thus, because there is little cost to retaining the school fixed effects, because the estimates are a bit different, and because including the school fixed effects does not introduce any bias, we view these as our preferred estimates.

\section{Provisional Summary}

To summarize, then, our analysis points to a number of beneficial effects from certain types of STC programs. In particular, job shadowing and school enterprise programs increase post-high school college attendance, while coop and internship/apprenticeship programs increase employment, although the statistical evidence for internship/apprenticeship programs is weaker. Finally, working in the other direction, tech prep programs appear to reduce college attendance without any offsetting increases in employment. Thus, this evidence suggests that specific types of STC programs can be used to increase post-secondary education and employment, and hence presumably to increase skill formation.

\section{Heterogeneity in the Effects of STC}

To this point we have reported estimated effects of STC participation for the full sample.

However, the effects of STC may differ across racial or ethnic groups, or across other characteristics of individuals that are associated with socioeconomic status or the likelihood of attending college (aside from STC). In fact, the "findings" on which the STWOA is based refer specifically to the problems posed by disadvantaged and minority youths. And STC practitioners commonly argue that STC programs are particularly helpful for such youths. We are also interested in how the effects of STC differ between men and women.

We therefore re-estimated some of our key specifications allowing the effects of STC to differ across groups. In each case, we maintained a single specification for the pooled sample, but interacted each of the STC participation variables with indicators for the groups considered (e.g., white, black, and Hispanic). We used the fixed effects specifications from Table 7, which for reasons discussed earlier we view as the most reliable estimates. Aside from race and ethnicity, we estimated models allowing 
different effects for: those in the top, middle, and bottom third of the distribution of the ASVAB math knowledge score; respondents whose biological mothers had 13 or more years of education and 12 or fewer years; respondents living with both biological parents and those with alternative living arrangements; and males and females. In the case of the math knowledge test, mother's education, and living arrangement variables, the estimates in Table 5B indicated that these were strongly related to college attendance. And all of the variables aside from the sex of the respondent are related to socioeconomic advantage.

Selected results are reported in Table 8 . To make the results easier to digest, for each specification only estimated coefficients of the STC-group interactions that are significantly different from zero for at least one group are reported. It is important to keep in mind, though, that in most cases the differences across groups were not statistically significant, in which case the pooled estimates reported in Table 7 cannot be rejected. The evidence in this table should be interpreted as simply establishing for which groups we can conclude that there are statistically significant effects of different STC programs.

Results from the specification allowing different effects by race and ethnicity are reported in columns (1)-(1'). Looking first at college attendance, there is generally more evidence of beneficial effects of STC programs for whites, as for whites only there are statistically significant positive effects of internship/apprenticeship programs on college attendance, and of coop and tech prep programs on employment. At the same time, two programs-tech prep and mentoring-have negative effects (on schooling and employment, respectively) only for whites. Also of note is that the only evidence of positive effects of internship/apprenticeship programs on employment arises for minorities, with the estimate statistically significant for blacks, large (but insignificant) for Hispanics, and near zero for 
whites. The earlier finding that school enterprise programs have positive effects on college attendance appears to apply to all groups, although the estimated effect is not statistically significant for blacks. ${ }^{20}$

The results disaggregating the effects by the ASVAB math knowledge score are reported next. There is no clear message here, as there are some positive and significant effects of alternative programs for each ability group. Columns (3) and (3') report results for the specification allowing different effects depending on the biological mother's education. Here, too, there is some evidence of positive program effects (for different programs) in each of the two groups. This is not the case, however, for the final specification, which allows the effects to differ depending on living arrangement. Here we see that there is no evidence of beneficial effects of STC for those in non-traditional families, and conversely all of the evidence of beneficial effects occurs for respondents living with both biological parents.

The estimates discussed to this point concern differences among respondents that are likely related to socioeconomic advantage or disadvantage. While it is difficult to synthesize the disparate estimates, some summary is possible. First, if we consider whites, those with high ASVAB scores, those with more-educated mothers, and those living with two biological parents as relatively advantaged, then a couple of conclusions emerge. First, job shadowing and mentoring have some beneficial effects on college attendance, but only for the more-advantaged individuals. There is some evidence of positive effects of school enterprise and internship/apprenticeship STC programs on college attendance for both more- and less-advantaged groups, and similarly some evidence of negative effects of tech prep programs on both more and less-advantaged individuals. Turning to employment, the evidence of positive effects of coop STC programs is strongest for more-advantaged individuals, while the evidence of positive effects of internship/apprenticeship programs arises only for less-advantaged individuals. Job shadowing appears to have some negative effects for both types of individuals.

\footnotetext{
${ }^{20}$ Finally, note that the results in Table 8 do not help explain the higher participation rates of blacks in coop, school enterprise, and tech prep programs, which were documented in Table 4. This suggests that explanations of these higher participation rates other than greater benefits for blacks should be explored, although that is beyond the scope of this study.
} 
Thus, the combined evidence does not permit any firm conclusion that the beneficial effects of STC programs are confined to either the more- or less-advantaged; certainly the evidence does not indicate that the benefits of STC accrue primarily or even relatively more to minorities and others who are less likely to attend college or more likely to face employment difficulties. Finally, there is some indication that internship/apprenticeship programs may be particularly advantageous for the lessadvantaged, as these programs boost college enrollment among those with the lowest test scores, and boost employment among blacks (and probably Hispanics) and among those with less-educated mothers.

The final two columns of Table 8 break out the results separately for men and women. There are some similarities with the combined estimates. In particular, the earlier findings that school enterprise STC programs boost post-secondary education and that coop programs boost employment appear to hold for both men and women; although in each case the estimates are not significantly different from zero for one sex, the estimates are very close for men and women. But there are also some striking differences. First, the finding that internship/apprenticeship programs boost employment is driven entirely by men, as for them the estimated effect $(0.125)$ is positive and significant, while for women it is near zero. Second, there are some other significant findings that emerge in the specifications allowing different effects for men and women. Specifically, it appears that job shadowing boosts post-secondary education for men, while internship/apprenticeship programs boost it for women. On the other hand, there is stronger evidence of a negative effect of tech prep on post-secondary education of women. However, for the estimates disaggregating the effects of STC by sex, the differences between the estimated effects (evaluated one program at a time) were never statistically significant at the ten-percent level. This differed from the case for the other breakdowns in Table 8 , where there were always significant differences for at least one of the STC programs. Thus, while the estimated sex differences are intriguing, we give them less weight.

\section{$\underline{\text { VI. Discussion and Conclusions }}$}

The empirical research presented in this paper attempts to estimate the causal effects of participation in school-to-career (STC) programs on further education and employment in the years 
immediately after individuals leave high school. The new National Longitudinal Survey of Youth (NLSY97) offers unparalleled opportunities to study this question, given a detailed battery of STC participation questions asked of respondents, a survey of schools attended by sample members soliciting information on STC offerings and other school characteristics, repeated observations on individuals in the same school, and a rich data set generally. Nonetheless, the fundamental problem faced by this research is the classic selection problem in program evaluation-namely, do those individuals with unmeasured characteristics associated with post-high school enrollment or employment participate in STC at different rates from other individuals?

The paper considers four approaches to address this selection problem: detailed control and proxy variables; controlling for prior expectations regarding work and schooling; instrumenting for individual STC participation with school-level offerings of STC programs; and school fixed effects. It turns out that school-level variation in offerings of STC programs is strongly associated with characteristics of schools and their students, suggesting that the IV approach is invalid. Rather, only the methods that use variation in STC participation within schools as identifying information are likely to recover unbiased estimates of the effects of STC. On a priori grounds (because it uses only within-school variation) and on empirical grounds the school fixed effects estimates are preferred. However, the evidence using the proxy variables and the prior expectations is quite similar, leading to a relatively robust set of findings.

Specifically, the evidence indicates that some STC programs (school enterprises) boost post-high school education (and tech prep may reduce it), and other STC programs (cooperative education and internships/apprenticeships) boost post-high school employment. ${ }^{21}$ The magnitudes implied by the estimates are reasonable yet also sizable, suggesting that participation in these programs boosts the probabilities of enrollment or employment by about 0.05 to 0.1 , relative to base probabilities of about 0.5 for college attendance and 0.6 for employment.

\footnotetext{
${ }^{21}$ There is also evidence that job shadowing boosts college enrollment, but this finding is not as robust across the alternative statistical analyses.
} 
Although not central to our analysis, there is also some evidence of differences in the effects of STC programs across groups distinguished by race and ethnicity and other characteristics associated with socioeconomic status, and across men and women. The most important finding regarding these differences is that STC does not appear to be particularly beneficial for disadvantaged students. Instead, there is some evidence of beneficial effects for all groups, although the programs that deliver the benefits vary.

Of course the findings presented in this paper fall short of the ideal of experimental evidence based on random assignment. While we believe that there is a clear need for more experimental evidence on the effects of STC, we also believe that the data in the NLSY97 offer compelling approaches to the selection problem. Indeed, we conjecture that in future work on the effectiveness of STC experimental evidence and analysis of secondary data sources with careful attention paid to endogenous selection will play complementary roles. Each has strengths and weaknesses, with experimental approaches offering the most compelling evidence, and analysis of secondary data yielding more generalizable results and permitting researchers to test a wider variety of hypotheses regarding different types of STC programs and different outcomes. 


\section{$\underline{\text { References }}$}

Angrist, Joshua D. 2001. "Estimation of Limited Dependent Variable Models with Dummy Endogenous Regressors: Simple Strategies for Empirical Practice." Journal of Business and Economic Statistics, Vol. 19, No. 1, pp. 2-28.

Card, David, and Alan B. Krueger. 1992. "Does School Quality Matter? Returns to Education and the Characteristics of Public Schools in the United States." Journal of Political Economy, Vol. 100, No. 1, February, pp. 1-40.

Chamberlain, Gary. 1980. "Analysis of Covariance with Qualitative Data." Review of Economic Studies, Vol. 47, No. 1, January, pp. 225-38.

Falaris, Evangelos M., and H. Elizabeth Peters. 1998. "Survey Attrition and Schooling Choices." Journal of Human Resources, Vol. 33, No. 2, Spring, pp. 531-54.

Heckman, James, Neil Hohmann, and Jeffrey A. Smith. 2000. "Substitution and Dropout Bias in Social Experiments: A Study of an Influential Social Experiment." Quarterly Journal of Economics, Vol. 115, No. 2, pp. 651-94.

Hershey, Alan M., Marsha K. Silverberg, and Joshua Haimson. 1999. Expanding Options for Students: Report to Congress on the National Evaluation of School-to-Work Implementation. Princeton, New Jersey: Mathematica Policy Research, Inc.

Hughes, Katherine L., Stephen F. Hamilton, and Robert J. Ivry. 2001. School-to-Work: Making a Difference in Education. New York: Institute on Education and the Economy, Teachers College, Columbia University.

Kemple, James J., and Jason C. Snipes. 2000. Career Academies: Impacts on Students' Engagement and Performance in High School. Manpower Demonstration Research Corporation.

Kemple, James J. 2001. Career Academies: Impacts on Students' Initial Transitions to Post-Secondary Education and Employment. Manpower Demonstration Research Corporation.

Neumark, David. 2002. "Youth Labor Markets in the U.S.: Shopping Around vs. Staying Put." Review of Economics and Statistics, Vol. 84, No. 3, August, pp. 462-82.

Neumark, David, and Ann Allen. "What Do We Know About the Effects of School-to-Work? A Case Study of Michigan.” Forthcoming, Journal of Vocational Education Research.

Neumark, David, and Mary Joyce. 2001. "Evaluating School-to-Work Programs Using the New NLSY." Journal of Human Resources, Vol. 36, No. 4, Fall, pp. 666-702.

Office of Technology Assessment, United States Congress. 1995. Learning to Work: Making the Transition from School to Work (Publication No. OTA-HER 637). Washington, D.C.: U.S. Government Printing Office.

Stern, David, Neal Finkelstein, James R. Stone, John Latting, and Carolyn Dornsife. 1994. Research on School-to-Work Transition Programs in the United States. Berkeley, CA: National Center for Research in Vocational Education, University of California. 
Topel, Robert H., and Michael P. Ward. 1992. "Job Mobility and the Careers of Young Men." Quarterly Journal of Economics, Vol. CVII, No. 2, May, pp. 439-80.

Wooldridge, Jeffrey M. 2002. Econometric Analysis of Cross Section and Panel Data (Cambridge, MA: The MIT Press). 
Table 1: Linear Probability Estimates of School Characteristics Associated with Schools Offering STC, Individual-Based Estimates

\begin{tabular}{|c|c|c|c|c|c|c|c|}
\hline & Any STC & $\begin{array}{c}\text { Job } \\
\text { shadowing }\end{array}$ & Coop & $\begin{array}{c}\text { School } \\
\text { enterprise }\end{array}$ & $\begin{array}{l}\text { Tech } \\
\text { prep }\end{array}$ & Internship & Apprenticeship \\
\hline & (1) & (2) & (3) & (4) & (5) & (6) & (7) \\
\hline $\begin{array}{l}\text { Share with schools } \\
\text { offering }\end{array}$ & .930 & .650 & .595 & .211 & .534 & .436 & .260 \\
\hline \multicolumn{8}{|l|}{ Regression results: } \\
\hline Student/teacher ratio & $\begin{array}{c}-.008^{* * *,++} \\
(.003) \\
\end{array}$ & $\begin{array}{l}.007 \\
(.006)\end{array}$ & $\begin{array}{c}-.033^{* * *,+++} \\
(.005) \\
\end{array}$ & $\begin{array}{l}-.002 \\
(.005)\end{array}$ & $\begin{array}{l}-.001 \\
(.006)\end{array}$ & $\begin{array}{c}-.010^{*,+} \\
(.006) \\
\end{array}$ & $\begin{array}{c}-.009^{*,+} \\
(.005) \\
\end{array}$ \\
\hline Log size & $\begin{array}{c}.101^{* * *,+++} \\
(.034)\end{array}$ & $\begin{array}{l}-.002 \\
(.047)\end{array}$ & $\begin{array}{c}.251^{* * *,+++} \\
(.044)\end{array}$ & $\begin{array}{l}-.026 \\
(.036)\end{array}$ & $\begin{array}{l}.015 \\
(.054)\end{array}$ & $\begin{array}{c}.185^{* * *,+++} \\
(.046)\end{array}$ & $\begin{array}{c}.118^{* * *,+++} \\
(.036)\end{array}$ \\
\hline \multicolumn{8}{|l|}{$\begin{array}{l}\text { Proportion of students } \\
\text { involved in: }\end{array}$} \\
\hline ...Chronic truancy & $\begin{array}{c}.008 \\
(.215)\end{array}$ & $\begin{array}{l}.753^{* *,++} \\
(.346)\end{array}$ & $\begin{array}{l}.163 \\
(.358)\end{array}$ & $\begin{array}{l}.832^{* *,++} \\
(.367)\end{array}$ & $\begin{array}{l}-.116 \\
(.359)\end{array}$ & $\begin{array}{l}.890^{* *,++} \\
(.363)\end{array}$ & $\begin{array}{c}.398 \\
(.389)\end{array}$ \\
\hline ...Pregnancies & $\begin{array}{c}-.580^{* *,+} \\
(.268) \\
\end{array}$ & $\begin{array}{l}-.840 \\
(.539)\end{array}$ & $\begin{array}{l}-.785 \\
(.649) \\
\end{array}$ & $\begin{array}{c}-1.141^{*,+} \\
(.674)\end{array}$ & $\begin{array}{l}-.579 \\
(.583) \\
\end{array}$ & $\begin{array}{l}-.375 \\
(.591)\end{array}$ & $\begin{array}{r}-1.084^{+} \\
(.689)\end{array}$ \\
\hline ...Alcohol possession & $\begin{array}{l}.198 \\
(.456) \\
\end{array}$ & $\begin{array}{l}1.904^{*} \\
(1.160)\end{array}$ & $\begin{array}{c}1.173 \\
(1.341) \\
\end{array}$ & $\begin{array}{c}2.298^{* *,+} \\
(1.108) \\
\end{array}$ & $\begin{array}{c}.906 \\
(1.304) \\
\end{array}$ & $\begin{array}{l}-1.576 \\
(1.255)\end{array}$ & $\begin{array}{c}2.501^{* *,++} \\
(1.169) \\
\end{array}$ \\
\hline ...Drugs & $\begin{array}{l}.324 \\
(.273)\end{array}$ & $\begin{array}{c}-.817 \\
(1.141) \\
\end{array}$ & $\begin{array}{l}-.802^{*} \\
(1.052)\end{array}$ & $\begin{array}{c}-1.147^{*},+ \\
(.595) \\
\end{array}$ & $\begin{array}{l}.385 \\
(.802)\end{array}$ & $\begin{array}{c}1.849^{* *},++ \\
(.834)\end{array}$ & $\begin{array}{c}-1.637^{* *,++} \\
(.714) \\
\end{array}$ \\
\hline $\begin{array}{l}\text { Weapons on school } \\
\text { property }\end{array}$ & $\begin{array}{l}-.165 \\
(.544) \\
\end{array}$ & $\begin{array}{l}-1.248 \\
(1.620) \\
\end{array}$ & $\begin{array}{l}.577 \\
(1.400) \\
\end{array}$ & $\begin{array}{c}1.625 \\
(1.613) \\
\end{array}$ & $\begin{array}{l}-1.428 \\
(1.366) \\
\end{array}$ & $\begin{array}{c}-3.411^{* *,++} \\
(1.434)\end{array}$ & $\begin{array}{l}-.142 \\
(1.142)\end{array}$ \\
\hline $\begin{array}{l}\text { Proportion of teachers } \\
\text { with } 10+\text { years } \\
\text { experience }\end{array}$ & $\begin{array}{l}.043 \\
(.060)\end{array}$ & $\begin{array}{l}.019 \\
(.137)\end{array}$ & $\begin{array}{l}.140^{+} \\
(.143)\end{array}$ & $\begin{array}{l}-.101 \\
(.118)\end{array}$ & $\begin{array}{l}-.269^{*,+} \\
(.141)\end{array}$ & $\begin{array}{l}-.008 \\
(.141)\end{array}$ & $\begin{array}{l}-.140 \\
(.142)\end{array}$ \\
\hline $\begin{array}{l}\text { Proportion of teachers } \\
\text { with degree above } \\
\text { bachelor's }\end{array}$ & $\begin{array}{l}.036 \\
(.048)\end{array}$ & $\begin{array}{l}.106 \\
(.117)\end{array}$ & $\begin{array}{c}.059 \\
(1.145)\end{array}$ & $\begin{array}{l}.182^{*,+} \\
(.093)\end{array}$ & $\begin{array}{l}.053 \\
(.121)\end{array}$ & $\begin{array}{c}.362^{* * * *+++} \\
(.115)\end{array}$ & $\begin{array}{l}-.015 \\
(.118)\end{array}$ \\
\hline Teacher's salary $/ \$ 1000$ & $\begin{array}{c}-.008^{* * *,++} \\
(.003) \\
\end{array}$ & $\begin{array}{l}-.003 \\
(.006) \\
\end{array}$ & $\begin{array}{c}-.014^{* *,++} \\
(.006)\end{array}$ & $\begin{array}{c}-.015^{* *,++} \\
(.006)\end{array}$ & $\begin{array}{c}-.019^{* * *,+++} \\
(.006)\end{array}$ & $\begin{array}{l}-.006 \\
(.007) \\
\end{array}$ & $\begin{array}{l}.005 \\
(.005) \\
\end{array}$ \\
\hline Computer center/lab & $\begin{array}{l}-.002 \\
(.053)\end{array}$ & $\begin{array}{l}-.107 \\
(.084)\end{array}$ & $\begin{array}{l}.131 \\
(.110)\end{array}$ & $\begin{array}{l}-.034 \\
(.098)\end{array}$ & $\begin{array}{c}.237^{* *,++} \\
(.097)\end{array}$ & $\begin{array}{l}.004 \\
(.114) \\
\end{array}$ & $\begin{array}{l}.125^{*,+} \\
(.071)\end{array}$ \\
\hline Receives Title I & $\begin{array}{l}-.024 \\
(.022)\end{array}$ & $\begin{array}{l}.001 \\
(.049)\end{array}$ & $\begin{array}{l}-.023 \\
(.046)\end{array}$ & $\begin{array}{l}-.034 \\
(.045)\end{array}$ & $\begin{array}{l}.027 \\
(.057)\end{array}$ & $\begin{array}{l}-.061 \\
(.056)\end{array}$ & $\begin{array}{l}-.038 \\
(.045)\end{array}$ \\
\hline $\begin{array}{l}\text { Receives National } \\
\text { School Lunch }\end{array}$ & $\begin{array}{l}.013 \\
(.035)\end{array}$ & $\begin{array}{l}.105 \\
(.067)\end{array}$ & $\begin{array}{l}-.018 \\
(.064)\end{array}$ & $\begin{array}{l}.063 \\
(.044)\end{array}$ & $\begin{array}{l}-.018 \\
(.064)\end{array}$ & $\begin{array}{l}.077 \\
(.060)\end{array}$ & $\begin{array}{l}-.070 \\
(.060)\end{array}$ \\
\hline $\begin{array}{l}\text { Proportion of students } \\
\text { Hispanic or Latino }\end{array}$ & $\begin{array}{l}-.022 \\
(.054)\end{array}$ & $\begin{array}{l}-.264^{* *,+} \\
(.110)\end{array}$ & $\begin{array}{l}-.133 \\
(.109)\end{array}$ & $\begin{array}{l}.061 \\
(.089)\end{array}$ & $\begin{array}{l}-.005 \\
(.121)\end{array}$ & $\begin{array}{l}-.068 \\
(.122)\end{array}$ & $\begin{array}{l}-.094 \\
(.110)\end{array}$ \\
\hline $\begin{array}{l}\text { Proportion of students } \\
\text { black }\end{array}$ & $\begin{array}{l}-.007 \\
(.062)\end{array}$ & $\begin{array}{l}-.128 \\
(.092)\end{array}$ & $\begin{array}{l}-.027 \\
(.091)\end{array}$ & $\begin{array}{l}-.097 \\
(.072)\end{array}$ & $\begin{array}{l}.104 \\
(.092)\end{array}$ & $\begin{array}{l}-.116 \\
(.091)\end{array}$ & $\begin{array}{l}.046 \\
(.079)\end{array}$ \\
\hline $\begin{array}{l}\text { Proportion of students } \\
\text { limited English } \\
\text { proficient }\end{array}$ & $\begin{array}{l}-.038 \\
(.082)\end{array}$ & $\begin{array}{l}.144 \\
(.179)\end{array}$ & $\begin{array}{l}-.303 \\
(.194)\end{array}$ & $\begin{array}{l}-.060 \\
(.189)\end{array}$ & $\begin{array}{l}-.061 \\
(.204)\end{array}$ & $\begin{array}{l}-.256 \\
(.180)\end{array}$ & $\begin{array}{l}-.053 \\
(.195)\end{array}$ \\
\hline $\mathrm{R}^{2}$ & .099 & .052 & .153 & .083 & .067 & .101 & .084 \\
\hline
\end{tabular}

There are 1,868 observations. The sample included in this table is those individuals for which IV estimation of the regression models for employment and education outcomes could be estimated, since this analysis assesses IV estimation. ***, **, and * indicate that the estimated coefficients are significantly different from zero at the one-, five-, and ten-percent level, respectively. The table also provides information on the statistical significance of these school characteristics in specifications that include the full set of individual-level controls (see, e.g., the controls in Table 4). In particular, the superscripts,+++++ , and + after the asterisks indicate that the estimated coefficients when these other controls are added are significantly different from zero at the one-, five-, and ten-percent level, respectively. The signs of the significant estimates were never different including the controls. Information on STC offerings is from the 2000 School Survey. We use information only for the most recent school attended. Mentoring is included in the STC categories in the survey of individuals, but not in the school survey. Apprenticeships and internships are asked about separately on the school survey, but not the individual survey. Other school characteristics also come from the school survey. Private schools and vocational/technical schools are excluded. The teacher's salary is the normal yearly base with a master's degree and no experience. Dummy variables are included for missing data on some school characteristics. Standard errors are robust to heteroscedasticity, and were adjusted to account for the clustering of observations within schools, allowing for non-independence within schools and heteroscedasticity across schools. 
Table 2: Linear Probability Estimates of School Characteristics Associated with Schools Offering STC, School-Based Estimates

\begin{tabular}{|c|c|c|c|c|c|c|c|}
\hline & $\begin{array}{l}\text { Any } \\
\text { STC }\end{array}$ & $\begin{array}{c}\text { Job } \\
\text { shadowing }\end{array}$ & Coop & $\begin{array}{c}\text { School } \\
\text { enterprise }\end{array}$ & $\begin{array}{l}\text { Tech } \\
\text { prep }\end{array}$ & Internship & Apprenticeship \\
\hline & (1) & (2) & (3) & (4) & (5) & (6) & (7) \\
\hline Share of schools offering & .926 & .654 & .493 & .225 & .519 & .363 & .243 \\
\hline \multicolumn{8}{|l|}{ Regression results: } \\
\hline Student/teacher ratio & $\begin{array}{l}-.003 \\
(.003)\end{array}$ & $\begin{array}{l}.011^{* *} \\
(.005)\end{array}$ & $\begin{array}{l}-.016^{* * *} \\
(.005)\end{array}$ & $\begin{array}{l}-.003 \\
(.004)\end{array}$ & $\begin{array}{l}-.005 \\
(.006)\end{array}$ & $\begin{array}{l}-.002 \\
(.005)\end{array}$ & $\begin{array}{l}-.005 \\
(.004)\end{array}$ \\
\hline Log size & $\begin{array}{l}.079^{* * *} \\
(.026)\end{array}$ & $\begin{array}{l}-.008 \\
(.035)\end{array}$ & $\begin{array}{l}.211^{* * * *} \\
(.032)\end{array}$ & $\begin{array}{l}.041 \\
(.028)\end{array}$ & $\begin{array}{l}.078^{* *} \\
(.037)\end{array}$ & $\begin{array}{l}.149^{* * *} \\
(.035)\end{array}$ & $\begin{array}{l}.098^{* * *} \\
(.027)\end{array}$ \\
\hline \multicolumn{8}{|l|}{$\begin{array}{l}\text { Proportion of students involved } \\
\text { in: }\end{array}$} \\
\hline ...Chronic truancy & $\begin{array}{l}.067 \\
(.159)\end{array}$ & $\begin{array}{l}.729^{* *} \\
(.286)\end{array}$ & $\begin{array}{l}-.055 \\
(.332)\end{array}$ & $\begin{array}{l}1.122^{* * *} \\
(.326)\end{array}$ & $\begin{array}{l}-.565^{* *} \\
(.279)\end{array}$ & $\begin{array}{l}.446 \\
(.334)\end{array}$ & $\begin{array}{l}.099 \\
(.254)\end{array}$ \\
\hline ...Pregnancies & $\begin{array}{l}-.181 \\
(.297)\end{array}$ & $\begin{array}{l}-.833 \\
(.545)\end{array}$ & $\begin{array}{l}-.771 \\
(.576)\end{array}$ & $\begin{array}{l}-.715^{*} \\
(.387)\end{array}$ & $\begin{array}{l}-.277 \\
(.546)\end{array}$ & $\begin{array}{l}-.282 \\
(.523)\end{array}$ & $\begin{array}{r}.335 \\
(.508) \\
\end{array}$ \\
\hline ...Alcohol possession & $\begin{array}{c}.432 \\
(.297) \\
\end{array}$ & $\begin{array}{l}1.842^{* *} \\
(.784)\end{array}$ & $\begin{array}{c}1.054 \\
(1.063)\end{array}$ & $\begin{array}{l}2.280^{* *} \\
(.944)\end{array}$ & $\begin{array}{l}1.503^{*} \\
(.823)\end{array}$ & $\begin{array}{l}-.020 \\
(.106)\end{array}$ & $\begin{array}{r}.404 \\
(.718) \\
\end{array}$ \\
\hline ...Drugs & $\begin{array}{l}.055 \\
(.298) \\
\end{array}$ & $\begin{array}{l}-.964 \\
(.774)\end{array}$ & $\begin{array}{l}-.178 \\
(.815) \\
\end{array}$ & $\begin{array}{l}-.193 \\
(.629) \\
\end{array}$ & $\begin{array}{l}.876 \\
(.574) \\
\end{array}$ & $\begin{array}{l}.780 \\
(.824) \\
\end{array}$ & $\begin{array}{l}-.946^{* * *} \\
(.402)\end{array}$ \\
\hline $\begin{array}{l}\text {... Weapons on school } \\
\text { property }\end{array}$ & $\begin{array}{l}-.512 \\
(1.029) \\
\end{array}$ & $\begin{array}{l}-1.372 \\
(1.430) \\
\end{array}$ & $\begin{array}{l}-.434 \\
(1.639)\end{array}$ & $\begin{array}{l}-.525 \\
(.117)\end{array}$ & $\begin{array}{l}-2.093^{*} \\
(1.222)\end{array}$ & $\begin{array}{c}.022 \\
(1.365)\end{array}$ & $\begin{array}{l}.014 \\
(.973)\end{array}$ \\
\hline $\begin{array}{l}\text { Proportion of teachers with } 10+ \\
\text { years experience }\end{array}$ & $\begin{array}{l}.019 \\
(.039)\end{array}$ & $\begin{array}{l}-.012 \\
(.152)\end{array}$ & $\begin{array}{l}-.165 \\
(.133)\end{array}$ & $\begin{array}{l}.065 \\
(.126)\end{array}$ & $\begin{array}{l}-.291^{* *} \\
(.132)\end{array}$ & $\begin{array}{l}-.050 \\
(.102)\end{array}$ & $\begin{array}{l}.096 \\
(.146)\end{array}$ \\
\hline $\begin{array}{l}\text { Proportion of teachers with } \\
\text { degree above bachelor's }\end{array}$ & $\begin{array}{l}.009 \\
(.039)\end{array}$ & $\begin{array}{l}.163 \\
(.102) \\
\end{array}$ & $\begin{array}{l}.108 \\
(.103)\end{array}$ & $\begin{array}{r}.078 \\
(.102) \\
\end{array}$ & $\begin{array}{l}.057 \\
(.105)\end{array}$ & $\begin{array}{l}.355^{* * *} \\
(.092)\end{array}$ & $\begin{aligned} .021 \\
(.092)\end{aligned}$ \\
\hline Teacher's salary & $\begin{array}{l}-.008^{* * *} \\
(.003)\end{array}$ & $\begin{array}{l}-.007 \\
(.005)\end{array}$ & $\begin{array}{l}-.005 \\
(.005)\end{array}$ & $\begin{array}{l}-.011^{*} \\
(.006)\end{array}$ & $\begin{array}{l}-.018^{* * *} \\
(.005)\end{array}$ & $\begin{array}{l}-.008 \\
(.005)\end{array}$ & $\begin{array}{l}-.001 \\
(.004)\end{array}$ \\
\hline Computer center/lab & $\begin{array}{l}-.057^{*} \\
(.033)\end{array}$ & $\begin{array}{l}-.051 \\
(.093)\end{array}$ & $\begin{array}{l}.060 \\
(.095)\end{array}$ & $\begin{array}{c}.083 \\
(.066) \\
\end{array}$ & $\begin{array}{l}.126 \\
(.088)\end{array}$ & $\begin{array}{l}-.118 \\
(.087)\end{array}$ & $\begin{array}{r}.052 \\
(.074)\end{array}$ \\
\hline Receives Title I & $\begin{array}{l}-.027 \\
(.021)\end{array}$ & $\begin{array}{l}-.020 \\
(.047)\end{array}$ & $\begin{array}{l}-.073 \\
(.046)\end{array}$ & $\begin{array}{l}-.027 \\
(.040)\end{array}$ & $\begin{array}{l}.020 \\
(.045)\end{array}$ & $\begin{array}{l}-.001 \\
(.045)\end{array}$ & $\begin{array}{l}-.069^{*} \\
(.036)\end{array}$ \\
\hline $\begin{array}{l}\text { Receives National School } \\
\text { Lunch }\end{array}$ & $\begin{array}{l}-.011 \\
(.020)\end{array}$ & $\begin{array}{l}-.042 \\
(.042)\end{array}$ & $\begin{array}{l}.005 \\
(.046)\end{array}$ & $\begin{array}{l}.035 \\
(.028)\end{array}$ & $\begin{array}{l}.048 \\
(.049)\end{array}$ & $\begin{array}{l}-.047 \\
(.048)\end{array}$ & $\begin{array}{l}.019 \\
(.037)\end{array}$ \\
\hline $\begin{array}{l}\text { Proportion of students Hispanic } \\
\text { or Latino }\end{array}$ & $\begin{array}{l}.013 \\
(.043)\end{array}$ & $\begin{array}{l}-.135 \\
(.103)\end{array}$ & $\begin{array}{l}.001 \\
(.111)\end{array}$ & $\begin{aligned} .036 \\
(.097)\end{aligned}$ & $\begin{array}{l}.094 \\
(.099)\end{array}$ & $\begin{array}{l}-.182^{*} \\
(.101)\end{array}$ & $\begin{array}{l}-.160^{* *} \\
(.081)\end{array}$ \\
\hline Proportion of students black & $\begin{array}{l}-.122 \\
(.102)\end{array}$ & $\begin{array}{l}-.166 \\
(.114)\end{array}$ & $\begin{array}{l}.072 \\
(.114)\end{array}$ & $\begin{array}{l}-.062 \\
(.062)\end{array}$ & $\begin{array}{l}.096 \\
(.106)\end{array}$ & $\begin{array}{l}-.143^{* *} \\
(.068)\end{array}$ & $\begin{array}{l}.083 \\
(.098)\end{array}$ \\
\hline $\begin{array}{l}\text { Proportion of students limited } \\
\text { English proficient }\end{array}$ & $\begin{array}{l}-.025 \\
(.070)\end{array}$ & $\begin{array}{c}.216 \\
(.134)\end{array}$ & $\begin{array}{l}-.409^{* *} \\
(.159) \\
\end{array}$ & $\begin{array}{l}-.140 \\
(.143)\end{array}$ & $\begin{array}{l}.276^{*} \\
(.146) \\
\end{array}$ & $\begin{aligned} .106 \\
(.181)\end{aligned}$ & $\begin{array}{r}.046 \\
(.122) \\
\end{array}$ \\
\hline
\end{tabular}

There are 3,368 observations. ${ }^{* * *}, * *$, and $*$ indicate that the estimated coefficients are significantly different from zero at the one-, five-, and ten-percent level, respectively. For the analysis in this table, we simply use school-level observations, so there are no instances of multiple observations on the same school. Observations are weighted to make the sample of schools representative. Standard errors are robust to heteroscedasticity. See notes to Table 1 for additional details. 
Table 3: Sample Construction and Analysis Samples

\begin{tabular}{|l|c|}
\hline \multicolumn{1}{|c|}{ Sample inclusion criteria } & Number of observations \\
\hline \multicolumn{1}{|c|}{$(1)$} & $(2)$ \\
\hline Total sample in 1997 & 8,984 \\
\hline Interviewed in 1999 or 2000 & 8,510 \\
\hline Age $\geq 18$ at 1999 or 2000 interview & 5,047 \\
\hline Not enrolled in high school by 1999 or 2000 & 4,234 \\
\hline Answered STC questions covering high school after Round 1 & 3,347 \\
\hline Complete data on baseline controls & 3,279 \\
\hline $\begin{array}{l}\text { Baseline analysis sample: exclude private/vocational school } \\
\text { students }\end{array}$ & 2,933 \\
\hline $\begin{array}{l}\text { Subset of baseline analysis sample with multiple observations } \\
\text { per school }\end{array}$ & 2,230 \\
\hline $\begin{array}{l}\text { Subset of baseline analysis sample with data on work and } \\
\text { schooling expectations (asked only of those born 1980 and } \\
1981)\end{array}$ & 2,057 \\
\hline
\end{tabular}

We use the 1999 or 2000 interview as the "post-high school interview," choosing the earliest one at which the respondent is aged 18 or older and no longer enrolled in high school. More restrictive sample inclusion criteria are imposed in each successive row. Baseline controls include race/ethnicity, education, and family structure (whether respondent lives with one, two, or no biological parents, and which ones, and household size). When other control variables are introduced in the regression models dummy variables indicating missing data are included. 
Table 4: Linear Probability Estimates of Individual Characteristics Associated with STC Participation

\begin{tabular}{|c|c|c|c|c|c|c|c|}
\hline & Any STC & $\begin{array}{c}\text { Job } \\
\text { shadowing }\end{array}$ & Mentoring & Coop & $\begin{array}{c}\text { School } \\
\text { enterprise }\end{array}$ & Tech prep & $\begin{array}{c}\text { Internship / } \\
\text { apprenticeship }\end{array}$ \\
\hline Share participating & .415 & .175 & .084 & .135 & .067 & .110 & .097 \\
\hline \multicolumn{8}{|l|}{ Demographic: } \\
\hline Female & $\begin{array}{l}.008 \\
(.019)\end{array}$ & $\begin{array}{c}.023 \\
(.015)\end{array}$ & $\begin{array}{c}.014 \\
(.011)\end{array}$ & $\begin{array}{l}-.010 \\
(.014)\end{array}$ & $\begin{array}{c}.004 \\
(.010)\end{array}$ & $\begin{array}{l}-.027^{* *} \\
(.011)\end{array}$ & $\begin{array}{c}.004 \\
(.011)\end{array}$ \\
\hline Black & $\begin{array}{l}.063^{* *} \\
(.029)\end{array}$ & $\begin{array}{l}-.007 \\
(.024)\end{array}$ & $\begin{array}{l}.022 \\
(.015)\end{array}$ & $\begin{array}{l}.043^{* *} \\
(.020)\end{array}$ & $\begin{array}{l}.053^{* * *} \\
(.014)\end{array}$ & $\begin{array}{l}.057^{* * *} \\
(.018)\end{array}$ & $\begin{array}{l}.008 \\
(.015)\end{array}$ \\
\hline Hispanic & $\begin{array}{l}.022 \\
(.029)\end{array}$ & $\begin{array}{l}-.005 \\
(.022)\end{array}$ & $\begin{array}{l}.022 \\
(.017)\end{array}$ & $\begin{array}{l}.004 \\
(.019)\end{array}$ & $\begin{array}{l}.004 \\
(.014)\end{array}$ & $\begin{array}{l}.028 \\
(.018)\end{array}$ & $\begin{array}{l}.024 \\
(.017)\end{array}$ \\
\hline Age (months) & $\begin{array}{c}.011 \\
(.016)\end{array}$ & $\begin{array}{c}.012 \\
(.012)\end{array}$ & $\begin{array}{c}.005 \\
(.009)\end{array}$ & $\begin{array}{c}.007 \\
(.011)\end{array}$ & $\begin{array}{l}-.006 \\
(.008)\end{array}$ & $\begin{array}{l}-.000 \\
(.010)\end{array}$ & $\begin{array}{l}-.001 \\
(.009)\end{array}$ \\
\hline \multicolumn{8}{|l|}{$\begin{array}{l}\text { Living arrangement / } \\
\text { family: }\end{array}$} \\
\hline Urban & $\begin{array}{l}-.048^{*} \\
(.028)\end{array}$ & $\begin{array}{l}-.033 \\
(.023) \\
\end{array}$ & $\begin{array}{c}.004 \\
(.015)\end{array}$ & $\begin{array}{c}.004 \\
(.016)\end{array}$ & $\begin{array}{c}.002 \\
(.011) \\
\end{array}$ & $\begin{array}{l}-.039^{*} \\
(.021)\end{array}$ & $\begin{array}{l}-.002 \\
(.014)\end{array}$ \\
\hline $\begin{array}{l}\text { Biological parent \& step- } \\
\text { parent }\end{array}$ & $\begin{array}{l}-.003 \\
(.029)\end{array}$ & $\begin{array}{l}-.016 \\
(.023)\end{array}$ & $\begin{array}{l}-.016 \\
(.016)\end{array}$ & $\begin{array}{l}-.013 \\
(.019)\end{array}$ & $\begin{array}{l}.015 \\
(.016)\end{array}$ & $\begin{array}{l}.003 \\
(.018)\end{array}$ & $\begin{array}{l}-.000 \\
(.018)\end{array}$ \\
\hline Biological mother only & $\begin{array}{l}-.026 \\
(.024)\end{array}$ & $\begin{array}{l}-.035^{*} \\
(.019)\end{array}$ & $\begin{array}{l}-.034^{* * *} \\
(.012)\end{array}$ & $\begin{array}{c}.008 \\
(.017)\end{array}$ & $\begin{array}{l}-.010 \\
(.011)\end{array}$ & $\begin{array}{l}-.015 \\
(.015)\end{array}$ & $\begin{array}{l}-.016 \\
(.015)\end{array}$ \\
\hline Biological father only & $\begin{array}{l}.010 \\
(.053)\end{array}$ & $\begin{array}{l}-.025 \\
(.040)\end{array}$ & $\begin{array}{l}-.015 \\
(.030)\end{array}$ & $\begin{array}{l}.026 \\
(.040)\end{array}$ & $\begin{array}{l}.090 \\
(.030)\end{array}$ & $\begin{array}{l}.024 \\
(.037)\end{array}$ & $\begin{array}{l}-.048 \\
(.030)\end{array}$ \\
\hline Other arrangement & $\begin{array}{l}-.004 \\
(.047)\end{array}$ & $\begin{array}{l}-.033 \\
(.035)\end{array}$ & $\begin{array}{l}.032 \\
(.032)\end{array}$ & $\begin{array}{l}.002 \\
(.035)\end{array}$ & $\begin{array}{l}-.015 \\
(.026)\end{array}$ & $\begin{array}{l}-.019 \\
(.031)\end{array}$ & $\begin{array}{l}-.002 \\
(.030)\end{array}$ \\
\hline Household size & $\begin{array}{l}-.014^{* *} \\
(.006)\end{array}$ & $\begin{array}{l}0.005 \\
(.005)\end{array}$ & $\begin{array}{l}-.004 \\
(.004)\end{array}$ & $\begin{array}{l}-.000 \\
(.005)\end{array}$ & $\begin{array}{l}-.005 \\
(.003)\end{array}$ & $\begin{array}{l}-.001 \\
(.004)\end{array}$ & $\begin{array}{c}-.011^{* * *} \\
(.004)\end{array}$ \\
\hline Log household income & $\begin{array}{c}.006 \\
(.006) \\
\end{array}$ & $\begin{aligned} .006 \\
(.004) \\
\end{aligned}$ & $\begin{array}{c}.002 \\
(.003) \\
\end{array}$ & $\begin{array}{c}.001 \\
(.004) \\
\end{array}$ & $\begin{array}{l}.002^{*} \\
(.001) \\
\end{array}$ & $\begin{array}{l}-.001 \\
(.003) \\
\end{array}$ & $\begin{array}{c}.002 \\
(.004) \\
\end{array}$ \\
\hline $\begin{array}{l}\text { Biological mother's } \\
\text { schooling }\end{array}$ & $\begin{array}{l}-.001 \\
(.004)\end{array}$ & $\begin{array}{l}.000 \\
(.003)\end{array}$ & $\begin{array}{l}.001 \\
(.002)\end{array}$ & $\begin{array}{l}-.001 \\
(.002)\end{array}$ & $\begin{array}{l}-.001 \\
(.002)\end{array}$ & $\begin{array}{l}-.001 \\
(.002)\end{array}$ & $\begin{array}{l}.005^{* *} \\
(.002)\end{array}$ \\
\hline \multicolumn{8}{|l|}{ ASVAB: } \\
\hline Arithmetic reasoning & $\begin{array}{l}-.006 \\
(.020)\end{array}$ & $\begin{array}{l}-.001 \\
(.016) \\
\end{array}$ & $\begin{array}{l}-.013 \\
(.012) \\
\end{array}$ & $\begin{array}{l}-.002 \\
(.013) \\
\end{array}$ & $\begin{array}{l}-.006 \\
(.011) \\
\end{array}$ & $\begin{array}{l}.010 \\
(.014) \\
\end{array}$ & $\begin{array}{l}-.007 \\
(.012)\end{array}$ \\
\hline Word knowledge & $\begin{array}{l}-.011 \\
(.019)\end{array}$ & $\begin{array}{l}-.014 \\
(.015)\end{array}$ & $\begin{array}{c}.002 \\
(.011)\end{array}$ & $\begin{array}{c}.006 \\
(.012)\end{array}$ & $\begin{array}{c}.017 \\
(.011)\end{array}$ & $\begin{array}{l}.022^{*} \\
(.011)\end{array}$ & $\begin{array}{c}-.032^{* * *} \\
(.011)\end{array}$ \\
\hline Paragraph comprehension & $\begin{array}{l}-.016 \\
(.019) \\
\end{array}$ & $\begin{array}{l}-.007 \\
(.016) \\
\end{array}$ & $\begin{array}{l}-.006 \\
(.012) \\
\end{array}$ & $\begin{array}{c}-.012 \\
(.014) \\
\end{array}$ & $\begin{array}{l}.015 \\
(.010) \\
\end{array}$ & $\begin{array}{l}-.020 \\
(.012) \\
\end{array}$ & $\begin{array}{l}-.001 \\
(.012) \\
\end{array}$ \\
\hline Math knowledge & $\begin{array}{l}-.000 \\
(.019)\end{array}$ & $\begin{array}{l}-.015 \\
(.015)\end{array}$ & $\begin{array}{l}.013 \\
(.011)\end{array}$ & $\begin{array}{l}-.011 \\
(.013)\end{array}$ & $\begin{array}{l}-.012 \\
(.010)\end{array}$ & $\begin{array}{l}-.019 \\
(.012)\end{array}$ & $\begin{array}{l}.019^{*} \\
(.011)\end{array}$ \\
\hline \multicolumn{8}{|l|}{ School behaviors: } \\
\hline Threatened at school & $\begin{array}{l}.060^{* *} \\
(.025)\end{array}$ & $\begin{array}{l}.022 \\
(.019)\end{array}$ & $\begin{array}{l}.008 \\
(.013)\end{array}$ & $\begin{array}{l}.010 \\
(.018)\end{array}$ & $\begin{array}{l}.009 \\
(.013)\end{array}$ & $\begin{array}{l}.023 \\
(.016)\end{array}$ & $\begin{array}{l}.018 \\
(.016)\end{array}$ \\
\hline $\begin{array}{l}\text { Got into physical fight at } \\
\text { school }\end{array}$ & $\begin{array}{l}-.010 \\
(.031)\end{array}$ & $\begin{array}{l}-.021 \\
(.023)\end{array}$ & $\begin{array}{l}-.000 \\
(.017)\end{array}$ & $\begin{array}{c}.014 \\
(.023)\end{array}$ & $\begin{array}{c}.017 \\
(.018)\end{array}$ & $\begin{array}{l}-.022 \\
(.021)\end{array}$ & $\begin{array}{l}-.003 \\
(.019)\end{array}$ \\
\hline $\begin{array}{l}\text { Late with no excuse } 2+ \\
\text { times }\end{array}$ & $\begin{array}{l}-.009 \\
(.022)\end{array}$ & $\begin{array}{l}.018 \\
(.017)\end{array}$ & $\begin{array}{l}-.018 \\
(.012)\end{array}$ & $\begin{array}{l}-.009 \\
(.015)\end{array}$ & $\begin{array}{l}.020^{*} \\
(.012)\end{array}$ & $\begin{array}{l}-.002 \\
(.014)\end{array}$ & $\begin{array}{l}.010 \\
(.013)\end{array}$ \\
\hline Absent 2+ weeks & $\begin{array}{l}-.072^{* * *} \\
(.034)\end{array}$ & $\begin{array}{l}-.059^{*} \\
(.024) \\
\end{array}$ & $\begin{array}{l}-.024 \\
(.016) \\
\end{array}$ & $\begin{array}{l}-.046^{* *} \\
(.021)\end{array}$ & $\begin{array}{l}-.022 \\
(.016) \\
\end{array}$ & $\begin{array}{l}-.002 \\
(.025) \\
\end{array}$ & $\begin{array}{l}-.040^{* * *} \\
(.017)\end{array}$ \\
\hline $\mathbf{R}^{2}$ & .016 & .014 & .009 & .011 & .016 & .016 & .013 \\
\hline
\end{tabular}

There are 2,933 observations. $* * *, * *$, and $*$ indicate that the estimated coefficients are significantly different from zero at the one-, five-, and ten-percent level, respectively. Students in private schools and vocational/technical schools are excluded. Dummy variables are included for missing data on some individual variables. STC participation is measured based on responses from the 1998, 1999, and 2000 interviews regarding school-to-work participation while in high school; the 2000 data is used only if the 2000 interview is the post-high school interview defined in the notes to Table 3. All other variables are defined as of the first round (1997), with the exception of age, which is defined as of the interview at which STC participation is measured. The ASVAB test scores are standardized to have mean zero and standard deviation of one for the calibration sample that took the test. The subset of ASVAB scores we use are those that make up the AFQT. Standard errors are robust to heteroscedasticity, and were adjusted to account for the clustering of observations within schools, allowing for non-independence within schools and heteroscedasticity across schools. 
Table 5A: Linear Probability Estimates of Effects of STC Participation on College Attendance and Employment

\begin{tabular}{|c|c|c|c|c|c|c|c|c|}
\hline & \multicolumn{4}{|c|}{ Some College } & \multicolumn{4}{|c|}{ Employment } \\
\hline & (1) & (2) & (3) & (4) & $\left(1^{\prime}\right)$ & $\left(2^{\prime}\right)$ & $(3 \prime)$ & (4') \\
\hline Job shadowing & $\begin{array}{c}.015 \\
(.026)\end{array}$ & $\begin{array}{c}.016 \\
(.025)\end{array}$ & $\begin{array}{l}.042^{*} \\
(.024)\end{array}$ & $\begin{array}{c}.037 \\
(.023)\end{array}$ & $\begin{array}{l}.010 \\
(.024)\end{array}$ & $\begin{array}{c}.007 \\
(.024)\end{array}$ & $\begin{array}{c}.008 \\
(.024)\end{array}$ & $\begin{array}{c}.004 \\
(.024)\end{array}$ \\
\hline Mentoring & $\begin{array}{l}.066^{*} \\
(.036)\end{array}$ & $\begin{array}{c}.043 \\
(.034)\end{array}$ & $\begin{array}{c}.029 \\
(.031)\end{array}$ & $\begin{array}{c}.026 \\
(.031)\end{array}$ & $\begin{array}{l}-.051 \\
(.033)\end{array}$ & $\begin{array}{l}-.046 \\
(.033)\end{array}$ & $\begin{array}{l}-.046 \\
(.033)\end{array}$ & $\begin{array}{l}-.046 \\
(.033)\end{array}$ \\
\hline Coop & $\begin{array}{l}-.019 \\
(.028)\end{array}$ & $\begin{array}{l}-.004 \\
(.027)\end{array}$ & $\begin{array}{c}.010 \\
(.026)\end{array}$ & $\begin{array}{c}.007 \\
(.026)\end{array}$ & $\begin{array}{l}.073^{* * * *} \\
(.027)\end{array}$ & $\begin{array}{l}.071^{* * * *} \\
(.027)\end{array}$ & $\begin{array}{l}.072^{* * * *} \\
(.027)\end{array}$ & $\begin{array}{l}.071^{\text {**** }} \\
(.027)\end{array}$ \\
\hline $\begin{array}{l}\text { School } \\
\text { enterprise }\end{array}$ & $\begin{array}{l}.112^{* * * *} \\
(.037)\end{array}$ & $\begin{array}{l}.100^{* * * *} \\
(.036)\end{array}$ & $\begin{array}{l}.083^{* * *} \\
(.033)\end{array}$ & $\begin{array}{l}.088^{* * * *} \\
(.033)\end{array}$ & $\begin{array}{c}.030 \\
(.037)\end{array}$ & $\begin{array}{c}.024 \\
(.037)\end{array}$ & $\begin{array}{l}.020 \\
(.037)\end{array}$ & $\begin{array}{c}.021 \\
(.037)\end{array}$ \\
\hline Tech prep & $\begin{array}{l}-.059^{* *} \\
(.030)\end{array}$ & $\begin{array}{l}-.051^{*} \\
(.030)\end{array}$ & $\begin{array}{l}-.042 \\
(.029)\end{array}$ & $\begin{array}{l}-.042 \\
(.030)\end{array}$ & $\begin{array}{l}-.012 \\
(.028)\end{array}$ & $\begin{array}{l}-.017 \\
(.028)\end{array}$ & $\begin{array}{l}-.017 \\
(.028)\end{array}$ & $\begin{array}{l}-.018 \\
(.028)\end{array}$ \\
\hline $\begin{array}{l}\text { Internship / } \\
\text { apprenticeship }\end{array}$ & $\begin{array}{c}.045 \\
(.032)\end{array}$ & $\begin{array}{c}.021 \\
(.031)\end{array}$ & $\begin{array}{c}.022 \\
(.030) \\
\end{array}$ & $\begin{array}{c}.021 \\
(.030)\end{array}$ & $\begin{array}{l}.065^{* *} \\
(.030)\end{array}$ & $\begin{array}{l}.071^{* *} \\
(.030)\end{array}$ & $\begin{array}{l}.073^{* *} \\
(.030)\end{array}$ & $\begin{array}{l}.072^{* *} \\
(.030)\end{array}$ \\
\hline $\begin{array}{l}\text { Control } \\
\text { variables } \\
\text { included: }\end{array}$ & & & & & & & & \\
\hline Demographic & $\mathrm{X}$ & $\mathrm{X}$ & $\mathrm{X}$ & $\mathrm{X}$ & $\mathrm{X}$ & $\mathrm{X}$ & $\mathrm{X}$ & $\mathrm{X}$ \\
\hline $\begin{array}{l}\text { Living } \\
\text { arrangement / } \\
\text { family }\end{array}$ & & $\mathrm{X}$ & $\mathrm{X}$ & $\mathrm{X}$ & & $\mathrm{X}$ & $\mathrm{X}$ & $\mathrm{X}$ \\
\hline ASVAB & & & $\mathrm{X}$ & $\mathrm{X}$ & & & $\mathrm{X}$ & $\mathrm{X}$ \\
\hline $\begin{array}{l}\text { School } \\
\text { behaviors }\end{array}$ & & & & $\mathrm{X}$ & & & & $\mathrm{X}$ \\
\hline
\end{tabular}

There are 2,933 observations in all of the specifications. Estimated effect on relative probability of college attendance (columns (1)-(4) and employment (columns (1')-(4')) are reported. School and work outcomes are measured as of the post-high school interview (1999 or 2000). Asterisks denote statistical significance of the coefficient estimates, with $* * *, * *$, and * indicating that the estimate is significantly different from zero at the one-, five-, and ten-percent level, respectively. STC participation is defined as in Table 4 . The standard errors allow for general heteroscedasticity, and were adjusted to account for the clustering of observations within schools, allowing for non-independence within schools and heteroscedasticity across schools. The sets of control variables are listed in detail in Table 4. There are dummy variables for a small number of cases with missing data for the following variables: log household income; biological mother's schooling; ASVAB scores; and urban residence. 
Table 5B: Linear Probability Estimates of Control Variable Coefficients, College Attendance and Employment

\begin{tabular}{|c|c|c|}
\hline & Some College & Employment \\
\hline Specification & Table 5A, col. (4) & Table 5A, col. (4') \\
\hline & $(1)$ & $(2)$ \\
\hline \multicolumn{3}{|l|}{ Demographic: } \\
\hline Female & $\begin{array}{l}.090^{* * *} \\
(.017)\end{array}$ & $\begin{array}{l}-.017 \\
(.019)\end{array}$ \\
\hline Black & $\begin{array}{l}.060^{* * * *} \\
(.023)\end{array}$ & $\begin{array}{c}-.106^{* * *} \\
(.026)\end{array}$ \\
\hline Hispanic & $\begin{array}{c}.008 \\
(.024) \\
\end{array}$ & $\begin{array}{l}-.017 \\
(.027)\end{array}$ \\
\hline Age & $\begin{array}{l}.034^{* *} \\
(.014)\end{array}$ & $\begin{array}{l}.047^{* * * *} \\
(.015)\end{array}$ \\
\hline \multicolumn{3}{|l|}{ Living arrangement / family: } \\
\hline Urban & $\begin{array}{c}.027 \\
(.020)\end{array}$ & $\begin{array}{l}-.024 \\
(.022)\end{array}$ \\
\hline Biological parent \& step-parent & $\begin{array}{l}-.049^{*} \\
(.026)\end{array}$ & $\begin{array}{l}.085^{* * * *} \\
(.028)\end{array}$ \\
\hline Biological mother only & $\begin{array}{c}-.108^{* * *} \\
(.021)\end{array}$ & $\begin{array}{c}.031 \\
(.024)\end{array}$ \\
\hline Biological father only & $\begin{array}{l}-.088^{*} \\
(.050)\end{array}$ & $\begin{array}{l}.178^{* * * *} \\
(.044)\end{array}$ \\
\hline Other arrangement & $\begin{array}{c}-.068 \\
(.044)\end{array}$ & $\begin{array}{c}.001 \\
(.050)\end{array}$ \\
\hline Household size excluding youth & $\begin{array}{c}-.015^{* * *} \\
(.006)\end{array}$ & $\begin{array}{c}.005 \\
(.006)\end{array}$ \\
\hline Log household income & $\begin{array}{l}.010^{* *} \\
(.004)\end{array}$ & $\begin{array}{c}.002 \\
(.006)\end{array}$ \\
\hline Biological mother's schooling & $\begin{array}{l}.023^{* * *} \\
(.003)\end{array}$ & $\begin{array}{c}.011^{* * *} \\
(.003)\end{array}$ \\
\hline \multicolumn{3}{|l|}{ ASVAB: } \\
\hline Arithmetic reasoning & $\begin{array}{c}-.011 \\
(.017)\end{array}$ & $\begin{array}{c}-.014 \\
(.019)\end{array}$ \\
\hline Word knowledge & $\begin{array}{l}.047^{* * * *} \\
(.017)\end{array}$ & $\begin{array}{c}.032 \\
(.019) \\
\end{array}$ \\
\hline Paragraph comprehension & $\begin{array}{c}.014 \\
(.017)\end{array}$ & $\begin{array}{c}.007 \\
(.019) \\
\end{array}$ \\
\hline Math knowledge & $\begin{array}{l}.156^{* * *} \\
(.016)\end{array}$ & $\begin{array}{l}-.009 \\
(.019)\end{array}$ \\
\hline \multicolumn{3}{|l|}{ School behaviors: } \\
\hline Threatened at school & $\begin{array}{c}-.078^{* * *} \\
(.023)\end{array}$ & $\begin{array}{c}-.027 \\
(.023)\end{array}$ \\
\hline Got into physical fight at school & $\begin{array}{c}-.096^{* * *} \\
(.025)\end{array}$ & $\begin{array}{c}-.080^{* * *} \\
(.030)\end{array}$ \\
\hline Late with no excuse $2+$ times & $\begin{array}{c}-.039^{* * *} \\
(.020)\end{array}$ & $\begin{array}{c}.003 \\
(.022)\end{array}$ \\
\hline Absent $2+$ weeks & $\begin{array}{c}-.121^{* * *} \\
(.028)\end{array}$ & $\begin{array}{l}-.044 \\
(.032) \\
\end{array}$ \\
\hline
\end{tabular}

All specifications correspond to Table 5A, columns (4) and (4'). See notes to Table 5A for details. 
Table 6: Linear Probability Estimates of Effects of STC Participation on College Attendance and Employment, Incorporating Prior Work and Schooling Expectations

\begin{tabular}{|l|c|c|c|c|}
\hline & \multicolumn{2}{|c|}{ Some College } & \multicolumn{2}{c|}{ Employment } \\
\hline & $(1)$ & $(2)$ & $(1 ')$ & $\left(2^{\prime}\right)$ \\
\hline Job shadowing & .024 & .014 & .026 & .027 \\
& $(.028)$ & $(.027)$ & $(.030)$ & $(.030)$ \\
\hline Mentoring & .019 & -.008 & -.016 & -.015 \\
& $(.039)$ & $(.038)$ & $(.041)$ & $(.041)$ \\
\hline Coop & .021 & .030 & .047 & .043 \\
& $(.031)$ & $(.030)$ & $(.033)$ & $(.033)$ \\
\hline School enterprise & $.113^{* * *}$ & $.104^{* * *}$ & -.013 & -.007 \\
& $(.040)$ & $(.039)$ & $(.048)$ & $(.049)$ \\
\hline Tech prep & -.046 & -.016 & .015 & .014 \\
& $(.038)$ & $(.035)$ & $(.033)$ & $(.033)$ \\
\hline Internship / apprenticeship & .012 & .016 & $.072^{* *}$ & $.072^{* *}$ \\
& $(.036)$ & $(.035)$ & $(.036)$ & $(.036)$ \\
\hline Expectations: & & & & \\
\hline $\begin{array}{l}\text { High school diploma by age } \\
\text { 20 }\end{array}$ & $\ldots$ & .010 & $\ldots$ & .017 \\
\hline 4-year degree by age 30 & $\ldots$ & $. .072)$ & & $(.090)$ \\
\hline $\begin{array}{l}\text { Work over 20 hours/week at } \\
\text { age 30 }\end{array}$ & $\ldots$ & .054 & $\ldots$ &. $.111^{* * *}$ \\
\end{tabular}

There are 2,057 observations, because the sample is restricted to those born in 1980 and 1981 for which the expectations data are available. See notes to Tables 4 and 5A for details. All of the specifications include the demographic, living arrangement/family, ASVAB, and school behavior variables that are the same as those included in columns (4) and (4') of Table 5A. The standard errors allow for general heteroscedasticity, and were adjusted to account for the clustering of observations within schools, allowing for non-independence within schools and heteroscedasticity across schools. 
Table 7: School Fixed Effects Linear Probability Estimates of Effects of STC

Participation on College Attendance and Employment

\begin{tabular}{|l|c|c|c|c|}
\hline & \multicolumn{2}{|c|}{ Some College } & \multicolumn{2}{c|}{ Employment } \\
\hline & $(1)$ & $(2)$ & $\left(1^{\prime}\right)$ & $(2 ')$ \\
\hline Job shadowing & .035 & $.063^{* *}$ & -.013 & -.018 \\
& $(.027)$ & $(.030)$ & $(.028)$ & $(.035)$ \\
\hline Mentoring & .018 & .048 & -.049 & -.073 \\
& $(.034)$ & $(.039)$ & $(.036)$ & $(.046)$ \\
\hline Coop & .004 & -.013 & $.073^{* *}$ & $.089^{* *}$ \\
& $(.031)$ & $(.035)$ & $(.032)$ & $(.037)$ \\
\hline School enterprise & $.091^{* *}$ & $.133^{* * *}$ & -.007 & -.024 \\
& $(.038)$ & $(.048)$ & $.047)$ & $(.056)$ \\
\hline Tech prep & $-.070^{* *}$ & $-.095^{* *}$ & .006 & .030 \\
& $(.036)$ & $(.040)$ & $(.032)$ & $(.041)$ \\
\hline Internship / apprenticeship & .038 & .055 & $.123^{* * *}$ & $.072^{*}$ \\
& $(.036)$ & $(.041)$ & $(.035)$ & $(.042)$ \\
\hline Hausman test for excluding & $\ldots$ & .19 & $\ldots$ & .25 \\
school fixed effects, p-value & & & & \\
\hline School fixed effects & & $\mathrm{X}$ & & $\mathrm{X}$ \\
\hline
\end{tabular}

There are 2,230 observations, because only observations on respondents in schools with multiple observations are included. All of the specifications include the demographic, living arrangement/family, ASVAB, and school behavior variables that are the same as those included in columns (4) and (4') of Table 5A. See notes to Table 5A for details. The standard errors are robust to heteroscedasticity. The Hausman test is computed for the vector of STC coefficients. The test is based on random versus fixed effects, and comes from the regression form of the test with standard errors robust to general heteroscedasticity and non-independence of observations within schools (Wooldridge, 2002, Chapter 10). 
Table 8: School Fixed Effects Linear Probability Estimates of Effects of STC Participation on College Attendance and Employment, Specifications Interacting STC Participation with Respondent Characteristics

\begin{tabular}{|c|c|c|c|c|c|c|c|c|c|c|c|c|}
\hline \multicolumn{13}{|c|}{ Some College } \\
\hline & \multicolumn{3}{|c|}{ Race/ethnicity } & \multicolumn{3}{|c|}{$\begin{array}{c}\text { ASVAB math } \\
\text { knowledge Score }\end{array}$} & \multicolumn{2}{|c|}{$\begin{array}{c}\text { Biological mother's } \\
\text { education }\end{array}$} & \multicolumn{2}{|c|}{ Living arrangement } & \multicolumn{2}{|c|}{ Sex } \\
\hline & White & Black & Hispanic & High & Medium & Low & $\begin{array}{l}\text { Some } \\
\text { college }\end{array}$ & $\begin{array}{c}\text { High } \\
\text { school or } \\
\text { less }\end{array}$ & $\begin{array}{l}\text { Lives w/ } \\
\text { two bio. } \\
\text { parents }\end{array}$ & $\begin{array}{c}\text { Other } \\
\text { living arr. }\end{array}$ & Men & Women \\
\hline & (1) & $\left(1^{\prime}\right)$ & $\left(1{ }^{\prime \prime}\right)$ & (2) & $\left(2^{\prime}\right)$ & $\left(2{ }^{\prime \prime}\right)$ & (3) & $\left(3^{\prime}\right)$ & (4) & $\left(4^{\prime}\right)$ & (5) & $\left(5^{\prime}\right)$ \\
\hline Job shadowing & & & & & & & $.122^{* *}$ & & $.086^{* *}$ & & $.097^{* *}$ & .032 \\
\hline Mentoring & & & & $.122^{*}$ & .050 & .009 & & & & & .001 & $.087^{*}$ \\
\hline \multicolumn{13}{|l|}{ Coop } \\
\hline $\begin{array}{l}\text { School } \\
\text { enterprise }\end{array}$ & $.119^{* *}$ & .113 & $.253^{* *}$ & $.145^{* *}$ & $.193^{*}$ & .005 & $.166^{* *}$ & $.113^{*}$ & $.175^{*}$ & .083 & .113 & $.149^{* *}$ \\
\hline Tech prep & $-.166^{* *}$ & -.082 & .067 & & & & $-.222^{* * *}$ & -.033 & -.037 & $-.162^{* * *}$ & -.072 & $-.125^{* *}$ \\
\hline $\begin{array}{l}\text { Internship / } \\
\text { apprenticeship }\end{array}$ & $.084^{*}$ & -.042 & .086 & .054 & .052 & $.178^{\text {*x }}$ & & & $.090^{*}$ & .002 & .005 & $.100^{*}$ \\
\hline \multicolumn{13}{|c|}{ Employment } \\
\hline Job shadowing & & & & $-.150^{* *}$ & -.027 & .067 & $-.090^{*}$ & .029 & .047 & $-.119^{* *}$ & & \\
\hline Mentoring & $-.113^{*}$ & -.017 & -.037 & & & & & & $-.143^{* *}$ & .033 & & \\
\hline Coop & $.139^{* * *}$ & -.018 & .079 & .076 & .075 & $.126^{*}$ & $.158^{* * *}$ & .045 & $.127^{* * *}$ & .039 & $.087^{*}$ & .088 \\
\hline \multicolumn{13}{|l|}{$\begin{array}{l}\text { School } \\
\text { enterprise }\end{array}$} \\
\hline Tech prep & $.100^{*}$ & -.029 & -.101 & & & & & & & & & \\
\hline $\begin{array}{l}\text { Internship / } \\
\text { apprenticeship }\end{array}$ & .001 & $.204^{* *}$ & .148 & & & & .005 & $.147^{* *}$ & & & $.125^{* *}$ & .021 \\
\hline Range & $\ldots$ & $\ldots$ & $\ldots$ & $>.75$ & $0-.75$ & $<0$ & $\ldots$ & $\ldots$ & $\ldots$ & $\ldots$ & $\ldots$ & $\ldots$ \\
\hline Observations & 1,295 & 503 & 432 & 687 & 547 & 625 & 889 & 1,191 & 1,230 & 1,000 & 1,084 & 1,146 \\
\hline
\end{tabular}

See notes to Tables 5A and 7. Specifications include STC program participation interacted with dummy variables for each group. They include school fixed effects, and are in other respects identical to Table 7. The "high," "medium," and "low" cutoffs for the estimates in columns (2)-(2") were chosen to assign roughly one-third of each group to each sub-sample. Standard errors are not reported. 